\title{
14. LITHOLOGIC INTERPRETATION FROM GEOPHYSICAL LOGS IN HOLES 737B, 738C, 739C, AND 742A $^{1}$
}

\author{
Gilles Ollier ${ }^{2}$ and Benoit Mathis ${ }^{3}$
}

\begin{abstract}
During Leg 119 a full suite of geophysical logs was recorded in four holes drilled in the southern Indian Ocean. Holes 737B and 738C are located on the northern and southern Kerguelen Plateau, respectively, whereas Holes 739C and $742 \mathrm{~A}$ are located on the Antarctic Shelf in the Prydz Bay area. The sediments encountered on the Kerguelen Plateau consist mainly of fine siliceous or calcareous biogenic deposits accumulated during the past $100 \mathrm{~m}$.y. On the Antarctic Shelf, the formations encountered are of glacial origin and consist principally of diamictites.

The geophysical logs were correlated with the core descriptions in order to supplement the lithologic column in the four holes. The in-situ measured parameters used for lithologic interpretation in Holes 737B, 738C, and 742A are the natural radioactivity, the neutron porosity, the bulk density, the photoelectric effect, the $P$-wave sonic transit time, and the thorium, uranium and potassium content. Only a limited number of geophysical logs (natural radioactivity, $P$-wave sonic transit time, and resistivity) were recorded in Hole 739C. A lithologic interpretation is, however, proposed for this hole on the basis of the existing logs. The lithology inferred from the logs is determined by comparing the position in standard diagrams of plotted parameters, either untreated or calculated, with the position of mineralogic and lithologic poles (calcite, quartz, etc.). Also, lithologic information from cores was extrapolated in the non-recovered intervals, according to the log changes observed between recovered and non-recovered sections.

In the Kerguelen Plateau holes the radioactivity and uranium, thorium, and potassium logs were used to determine the amount and the nature of clays. Six logging units are recognized in Hole 737B in the depth interval 296.5-701.0 meters below seafloor (mbsf) and three in Hole 738C in the depth interval 113.0-455.0 mbsf on the basis of the shaliness and the porosity of the calcareous formations. Almost no clay was found from the logs in Hole $738 \mathrm{C}$, whereas a significant amount of illite and montmorillonite, up to $38.5 \%$ of the dry bulk, was found in Hole 737B.

Unlike the biogenic sediments of the Kerguelen Plateau, the deposits encountered in the holes of the Antarctic Shelf show a very high radioactivity rate (up to $120 \mathrm{GAPI}$ in Hole $742 \mathrm{~A}$ ) due to the presence of granitic eroded basement rocks. Two kinds of glacial sediments were identified from the log records in Hole 742A and 739 C. The first kind corresponds to compacted massive diamictite units deposited beneath grounded ice; the second kind corresponds to less compacted, stratified diamictite units deposited seaward of the grounding line. The basal glacier deposits are compacted because the weight of the ice has acted upon the sediments since the time of their deposit whereas distal diamictites are less affected by ice loading. In both Holes $739 \mathrm{C}$ and $742 \mathrm{~A}$, the alternation of basal diamictites and distal diamictites suggests several cycles of ice advance and recession. At least two cycles seem to have occurred from the Pliocene to the present.
\end{abstract}

\section{INTRODUCTION}

Core recovery at the sites drilled during Ocean Drilling Program (ODP) Leg 119 was only $57.6 \%$ on an average for the entire cruise (Barron, Larsen, et al., 1989). The present study is an attempt to use the geophysical logs recorded in Holes $737 \mathrm{~B}$, $738 \mathrm{C}, 739 \mathrm{C}$, and $742 \mathrm{~A}$ to supplement the lithologic observations from the cores.

These four holes document two kinds of sedimentary environments (Fig. 1). Holes 737B and 738C sampled the calcareous and siliceous biogenic sediments deposited during the past 100 m.y. on the Kerguelen Plateau (Barron, Larsen, et al., 1989). Prydz Bay Holes 739C and 742A on the Antarctic continental shelf sampled sediments from glaciomarine origin, of diamictite type, spanning at least $35 \mathrm{~m} . y$ (Barron, Larsen, et al., 1989; Hambrey et al., 1989; Hambrey et al., this volume)

Since the early 1970 's and concurrently with the development of sophisticated logging tools, the oil companies have developed methods allowing the interpretation of lithology from geophysical logs in the absence of coring from exploration holes (Schlum-

${ }^{1}$ Barron, J., Larsen, B., et al., 1991. Proc. ODP, Sci. Results, 119: College Station, TX (Ocean Drilling Program).

2 Institut Français de Recherche pour l'Exploitation de la Mer, Centre de Brest (IFREMER), BP 70, 29280, Plouzané, France.

${ }^{3}$ Laboratoire de Géologie des Ensembles Sédimentaires, Faculté des Sciences, Université de Nancy 1, BP 239, 54506 Vandoeuvre Les Nancy Cedex, France. berger, 1972a; Schlumberger, 1972b; Quirien et al., 1982; Serra, 1985; Herron, 1986). These methods are mostly based on the use of crossplots of measured parameters such as density and porosity, or calculated parameters derived from the former (Burke et al., 1969; Ellis, 1987; Schlumberger, 1988). The methods developed for the oil industry are, however, usually adapted to cemented, well-consolidated sediments such as limestone, sandstone, or dolomite, but have to be employed with special care to the non-lithified sediment types encountered in the present ODP holes. Nevertheless, applying proper corrections to the logging measurements, some authors have already used the crossplot methods in the ODP holes (Anderson and Newmark, 1985; Goldberg et al., 1987). Another way is to define a mineralogic model on the basis of the sampled intervals, and then to calculate the percentage of each mineral at each depth (Quirien et al., 1986; Doveton, 1986; Jarrard et al., 1989; Broglia et al., 1990).

The major difference between the sedimentary formations drilled for oil exploration and those recovered in the ODP holes is in the consolidation state of the sampled material. The sediments sampled during Leg 119 commonly reached $60 \%$ water content and $80 \%$ porosity on the Kerguelen Plateau, and $20 \%$ water content and $40 \%$ porosity in the Prydz Bay area (Barron, Larsen, et al., 1989). By comparison, the consolidated formations mainly exhibit water contents and porosities significantly lower; the water content is mostly equal to a few percent, whereas porosity rarely exceeds $40 \%$ (Serra, 1985). Also the hole conditions are significantly less favorable for logging acquisition in 


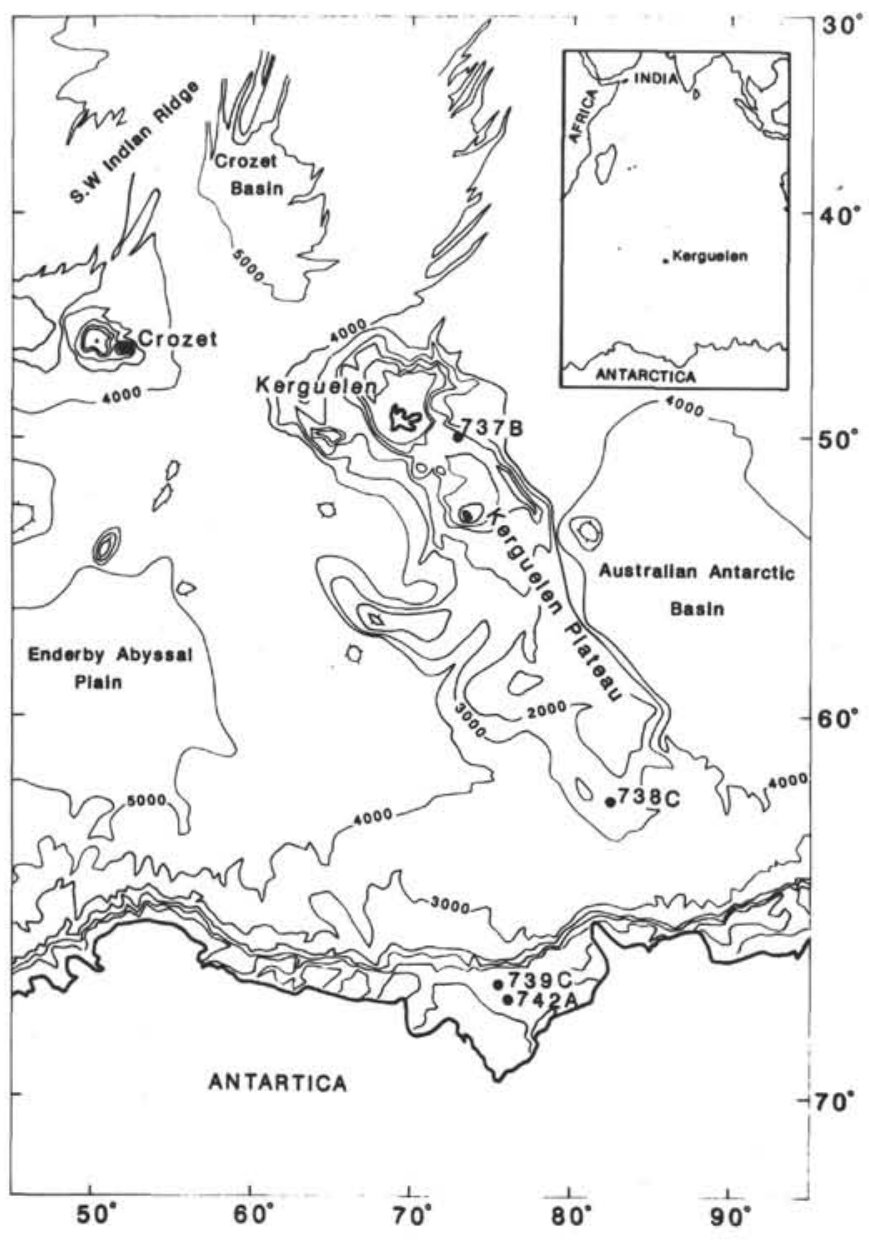

Figure 1. Location of Holes 737B, 738C, 739C, and 742A. Bathymetry, in meters, is from GEBCO (Hayes and Vogel, 1981; Fisher et al., 1982)

ODP drilling than in commercial drilling. The large size of the ODP holes (minimum 11 in., or $27.5 \mathrm{~cm}$, on Leg 119), combined with the frequent occurrence of soupy sediments and the influence of the drilling fluid on the logging tool responses, induce incorrect logging measurements (Lamont-Doherty Borehole Research Group, 1988). On the other hand, unlike exploration holes where coring is commonly restricted to the reservoir, the ODP holes are continuously cored, and offer an uncomparable opportunity to match observations from cores and from in-situ measurements. Accordingly, the core descriptions are used extensively in this study to calibrate the log responses in terms of lithology. The primary objective of this study is to fill the lithologic gaps of the non-recovered intervals. In addition, we aim to provide quantitative information, such as the porosity and the shaliness of the formations.

The following will successively present the description of the available data, the method used to derive the lithologies from geophysical logs, the log-inferred lithology in the Kerguelen Plateau holes, the log-inferred lithology in the Prydz Bay holes, and finally, a section will be devoted to a discussion of the validity of these results and their implications in the understanding of the local sedimentary environments.

\section{AVAILABLE DATA}

The term lithologic unit will be used in the following for the lithology defined by cores. The term logging unit will be used for the units defined by geophysical logs. The data used in this study are the Schlumberger geophysical logs, the lithologic core descriptions, and the density and porosity measured on samples presented in the preliminary leg results (Barron, Larsen, et al., 1989). Information about the mineralogic composition of the sediments recovered is also integrated into the present study (Hambrey, et al., this volume; Bohrmann and Ehrmann, this volume)

\section{Hole 737B}

In Hole 737B, geophysical logs are available between 124.0 and 701.0 mbsf (Fig. 2). Because of the lack of lithologic logs, such as density and porosity logs, in the upper logged section, a lithologic interpretation is only proposed for the depth interval 296.5-701.0 mbsf. The log-inferred lithologic column is represented between the radioactivity $\log$ (SGR) and the bulk density $\log$ (RHOB) (Fig. 3). The core recovery between 296.5 and 701.0 mbsf reaches $66.6 \%$. This depth interval contains four lithologic units (Barron, Larsen, et al., 1989): (1) lithologic Unit 3 (244.1-306.6 mbsf), (2) lithologic Unit 4 (306.6-321.1 mbsf), (3) lithologic Unit 5 (321.1-677.9 mbsf), (4) lithologic Unit 6, (677.9-711.2 mbsf).

Lithologic Unit 3 consists of middle to upper Miocene diatom-nannofossil ooze. Lithologic Unit 4 is a middle Miocene formation consisting of sandy siltstone mixed with volcanic sand and diatom-nannofossil oozes. Lithologic Unit 5 is an upper Oligocene to middle Eocene unit composed of calcareous claystone mixed with clayey limestone at its base. Lithologic Unit 6 is composed of a middle Eocene clayey limestone with minor chert layers, nodules, and black claystone. Physical properties and lithology are further described in Barron, Larsen, et al. (1989) which also contains comparison with the preliminary log results, and in Bohrmann and Ehrmann (this volume). The logging parameters recorded in Hole 737B are either physical parameters (such as bulk density (RHOB), neutron porosity (NPHI), $P$-wave sonic transit time (DT), total natural radioactivity (SGR) or natural radioactivity (GR), and photoelectric effect factor (PEF) parameters) or chemical parameters deduced from radioactivity (such as uranium (U), thorium (Th), and potassium (K) content). The previous parameters were acquired with the following tools which are commonly used in the oil industry and developed by Schlumberger (Ellis, 1987): lithodensity tool (LDT) for RHOB and PEF; dual porosity neutron tool (CNT-G) for NPHI; long-spaced sonic tool (LSS) for DT, natural gamma-ray tool (NGR) for GR; and natural gamma-ray spectrometry tool (NGT) for U, Th, K, and SGR.

\section{Hole $\mathbf{7 3 8 C}$}

In Hole $738 \mathrm{C}$, logs were acquired between 113.0 and 455.0 mbsf (Fig. 4) and used within this depth interval to supplement the lithology from cores (Fig. 5). In Figure 5, the log-inferred lithologic column is represented between the RHOB and the NPHI log. The mean core recovery is $57.6 \%$ for the entire drilled section. The core descriptions indicate that the logged section covers a calcareous sequence divided in four distinct units (Barron, Larsen, et al., 1989), (Fig. 5): (1) lithologic Unit 3 (17.7 to $120.8 \mathrm{mbsf}$ ), (2) lithologic Unit 4 (120.8 to 254.4 mbsf), (3) lithologic Unit 5 (254.4 to $418.6 \mathrm{mbsf}$ ), and (4) lithologic Unit 6 ( 418.6 to 479.7 mbsf).

Lithologic Unit 3 is described as a middle Eocene and lower Oligocene nannofossil ooze unit. Unit 4 consists of lower to middle Eocene nannofossil ooze and chalk-bearing chert layers. Unit 5 is a Campanian to lower Eocene chalk unit with chert nodules. Lithologic Unit 6 corresponds to a lower Turonian to Campanian silicified limestone. Further information about physical properties and lithology is described in Barron, Larsen, et al. (1989) and Ehrmann (this volume). The geophysical logs available in this hole are the same as in Hole 737B. 


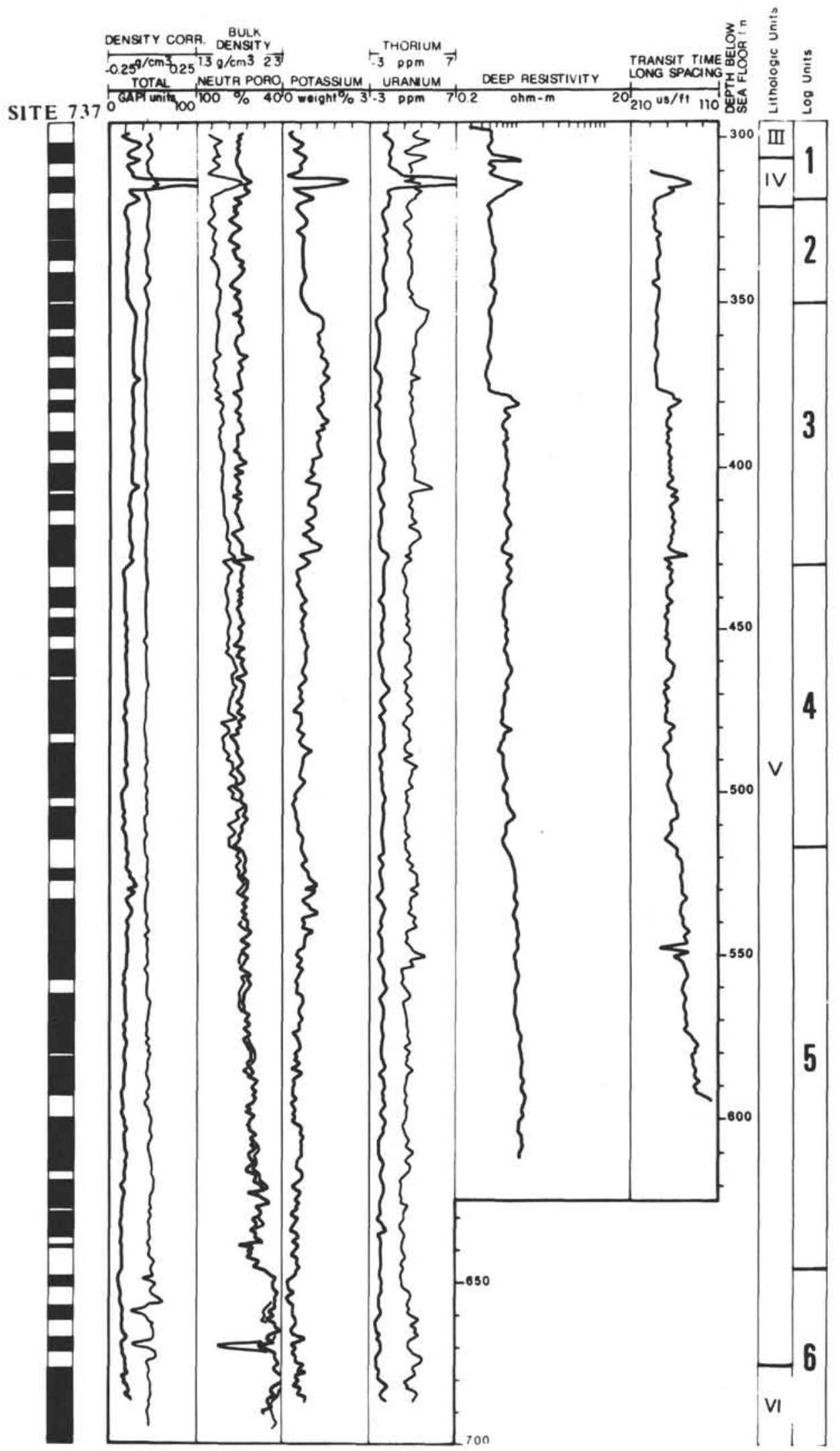

Figure 2. Core recovery, geophysical logs, lithologic units, and logging units in Hole 737B (modified from Barron, Larsen, et al., 1989). The geophysical logs consist of the total natural radioactivity, bulk density, neutron porosity, potassium content, thorium content, uranium content, deep resistivity, and long-spacing sonic transit time logs, acquired with the Schlumberger tools described in Ellis, 1987. (Note: Log curve thickness corresponds to underlining in legend at top.) 


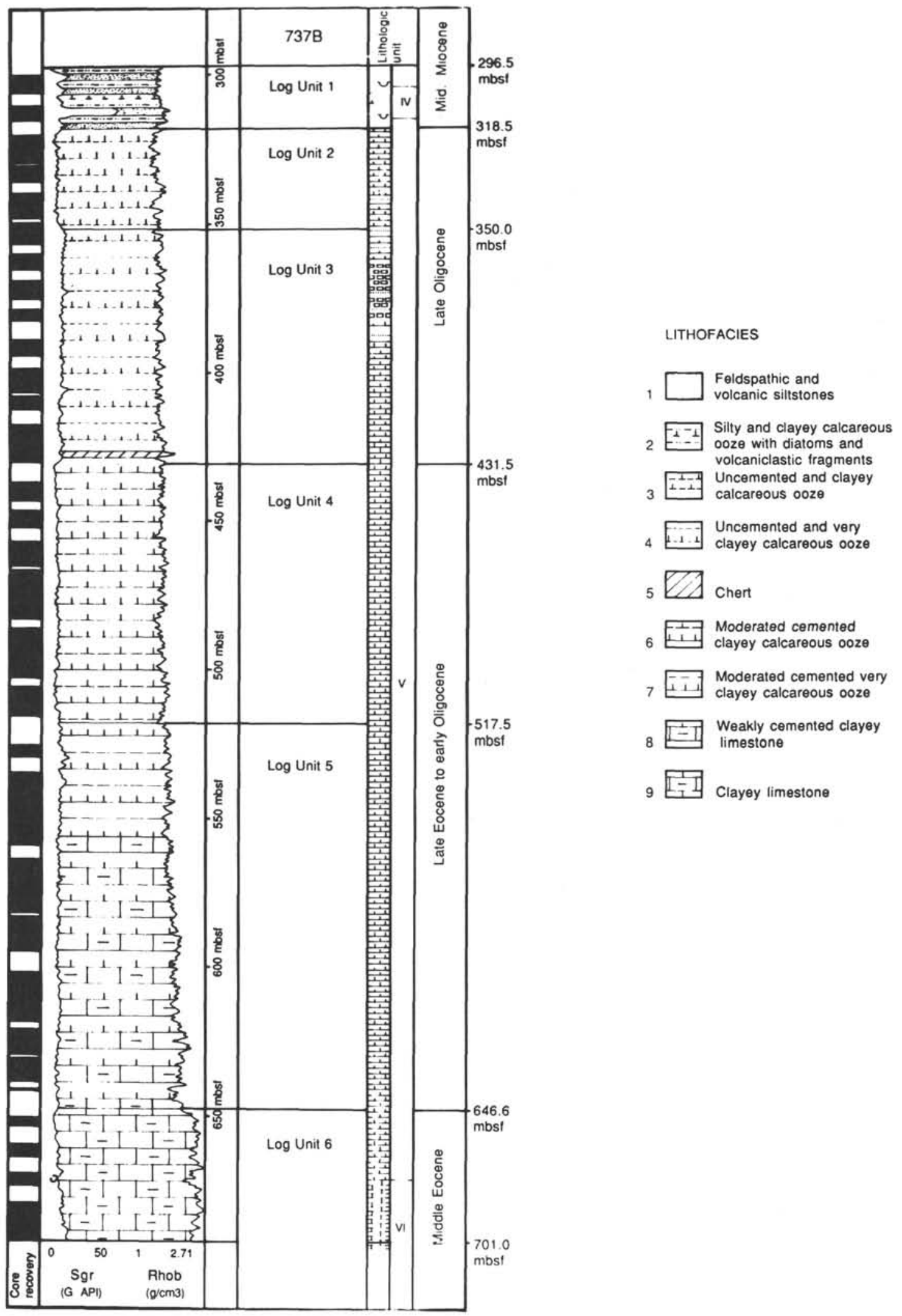

Figure 3. Core recovery, log-inferred lithologic column, lithologic units, and ages in Hole 737B. The log-inferred lithologic column is represented between the total radioactivity $\log$ (SGR) and the bulk density log (RHOB). The lithologic units and the ages are from Barron, Larsen, et al. (1989). 

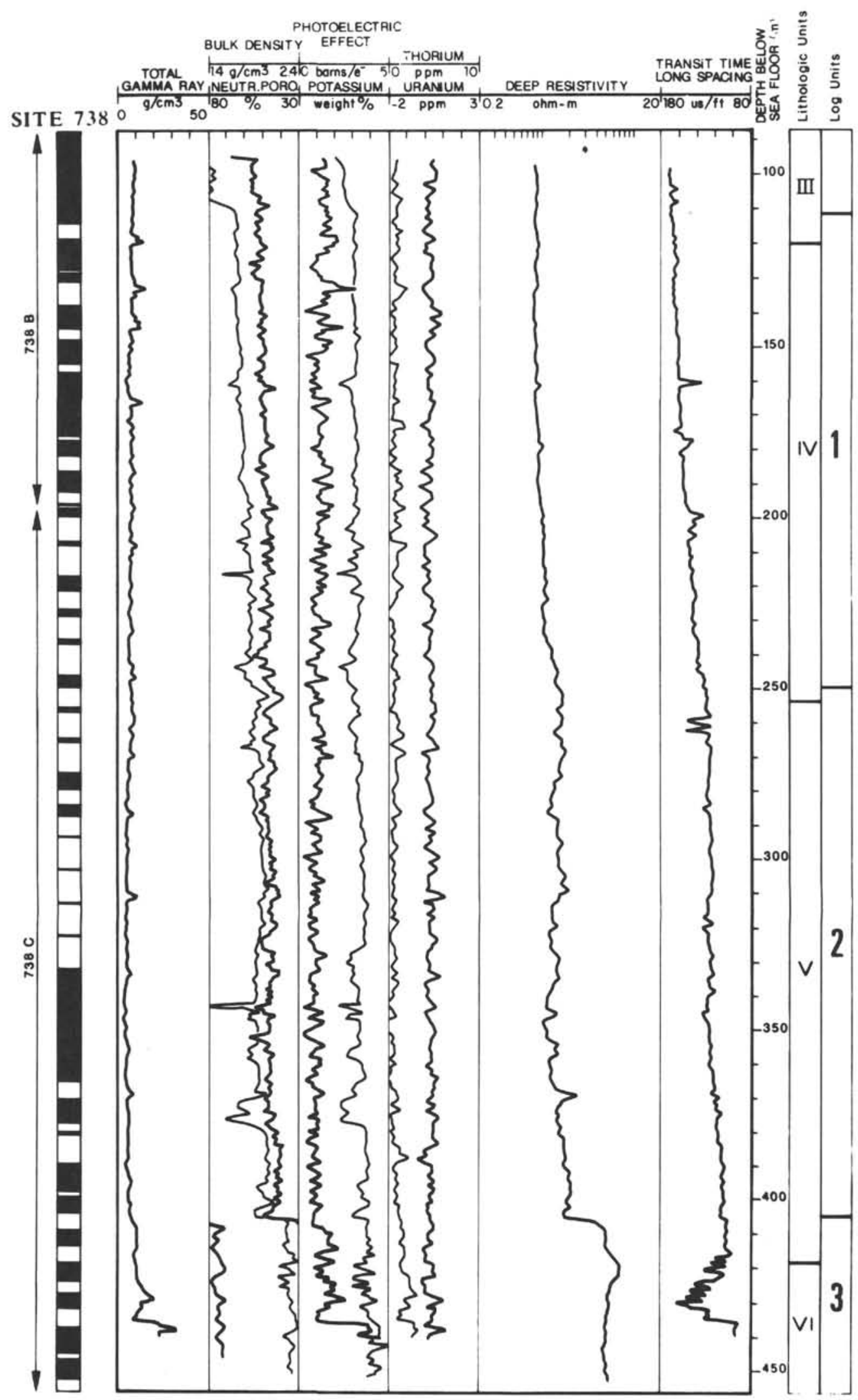

Figure 4. Core recovery, geophysical logs recorded, lithologic units, and logging units in Hole 738C (modified from Barron, Larsen, et al., 1989). The geophysical logs consist of the total natural radioactivity, bulk density, neutron porosity, photoelectric effect, potassium content, thorium content, uranium content, deep resistivity, and long-spacing sonic transit time logs, acquired with the Schlumberger tools described in Ellis, 1987. 


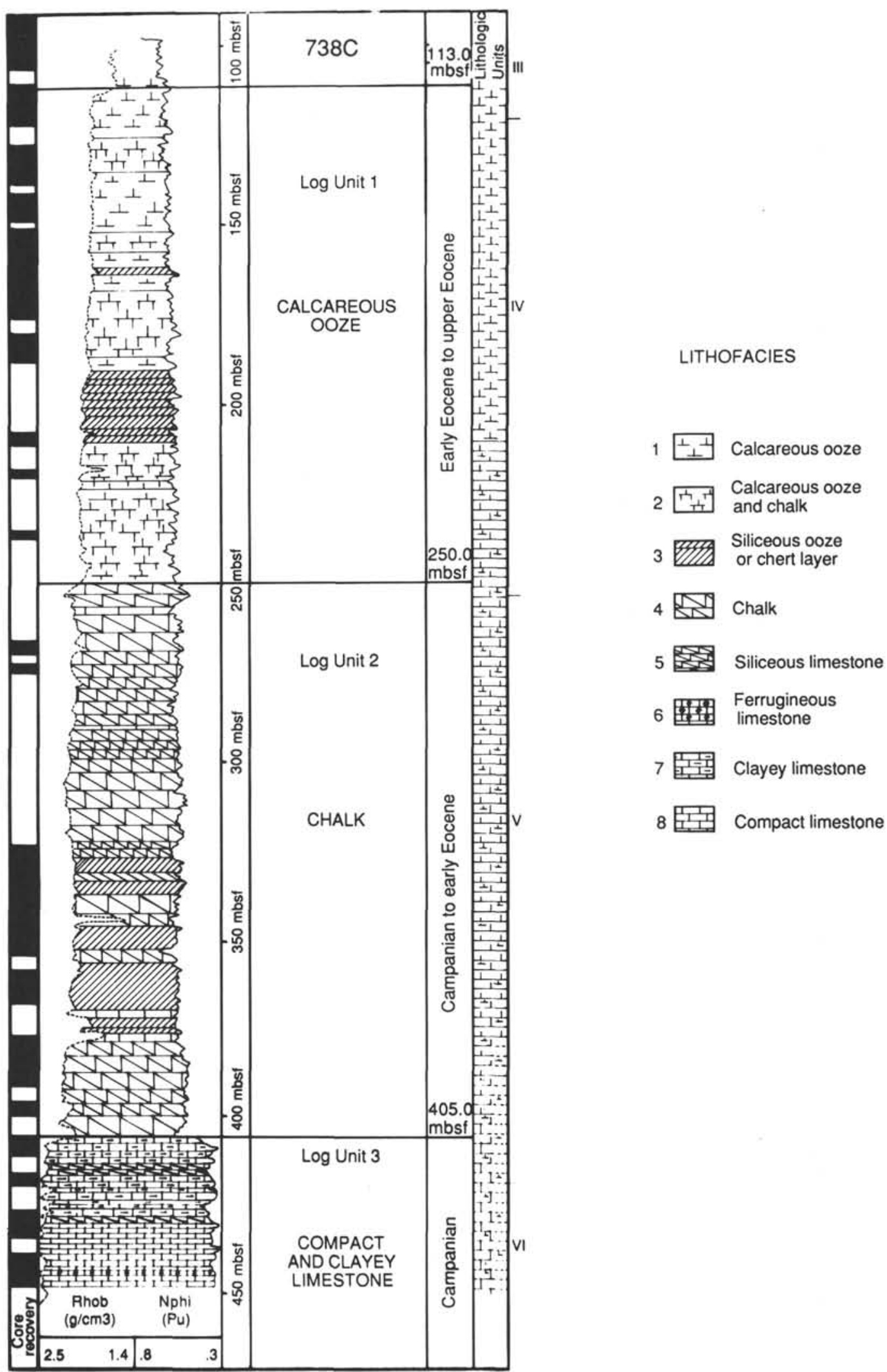

Figure 5. Core recovery, log-inferred lithologic column, ages, and lithologic units in Hole 738C. The log-inferred lithologic column is represented between the bulk density log (RHOB) and the neutron porosity log (NPHI). The ages and the lithologic units are from Barron, Larsen, et al. (1989). 


\section{Hole 742A}

The logging tools did not reach the bottom of Hole $742 \mathrm{~A}$ because of a bridge in the lower part of the drilled section (Fig. 6). Core recovery for the entire drilled section is $53.4 \%$. A lithologic interpretation from logs is proposed in this hole within the depth interval 30.8-283.8 mbsf (Fig. 7); this depth interval covers five lithologic units (Barron, Larsen, et al., 1989): (1) lithologic Unit 2 (5.4 to $115.2 \mathrm{mbsf}$ ), (2) lithologic Unit 3 (115.2 to $134.4 \mathrm{mbsf}$ ); (3) lithologic Unit 4 (134.4 to $172.5 \mathrm{mbsf}$ ), (4) lithologic Unit 5 (172.5 to $304.3 \mathrm{mbsf}$ ), and (5) lithologic Unit 6 (304.3 to $316.0 \mathrm{mbsf}$ ).

Lithologic Unit 2 is a massive diamictite unit containing the remains of late Pliocene-Quaternary diatoms. Lithologic Unit 3 is composed of normally consolidated clayey diamictites containing a 80 -cm-thick diatomite layer of early to late Pliocene age. Lithologic Unit 4 corresponds to a crudely layered diamictite unit with no biostratigraphic control. Diamictites of lithologic Unit 5 are characterized by pale colors and a minor calcareous component. Lithologic Unit 6 consists of diamictites interbedded with laminated claystone; for details see Barron, Larsen, et al. (1989) and Hambrey et al. (this volume). The logging records available in this Hole are the same as for Holes 737B and $738 \mathrm{C}$.

\section{Hole 739C}

Almost all of Hole $739 \mathrm{C}$ was logged, between 32.0 and 468.0 mbsf (Fig. 8). A lithologic interpretation from the cores and the logs is proposed for this logged interval (Fig. 9). Core recovery for the entire drilled section only reaches $35.3 \%$. The core description allowed the identification of four lithologic units (Barron, Larsen, et al., 1989; Hambrey, et al., this volume): (1) lithologic Unit 2 (24.1 to $173.6 \mathrm{mbsf}$ ), (2) lithologic Unit 3 (173.6 to $267.2 \mathrm{mbsf}$ ), (3) lithologic Unit 4 (267.2 to $315.7 \mathrm{mbsf}$ ), and (4) lithologic Unit 5 (315.7 to $468.8 \mathrm{mbsf}$ ).

Lithologic Unit 2 corresponds to an upper Miocene to lower Pliocene or younger massive diamictite. Lithologic Unit 3 is a stratified diamictite unit with a relatively diatom-rich layer of early Oligocene age. Lithologic Unit 4 consists of slightly indurated but friable diamictites, assigned to a lower Oligocene age. Lithologic Unit 5 is similar to Unit 4 but is of uncertain age (Barron, Larsen, et al., 1989).

Because of time constraints, only a limited number of geophysical logs were recorded in Hole 739C. The "lithologic logs," such as density, neutron porosity, photoelectric effect, and uranium, thorium, and potassium content logs, were not acquired, so the lithology interpretation from logs in this hole is mainly based on the resistivity $\log , P$-wave sonic $\log$, and GR log. The GR $\log$ is a radioactivity log which was recorded with the Schlumberger gamma-ray device instead of the gamma-ray spectrometry device used at the other holes (for details see Ellis, 1987). Calculated porosities ("PHI SON") (Fig. 10) were derived from the sonic transit time log by using the Raymer-Hunt equation (Raymer et al., 1980). We chose this method because on-core velocity measurements have been completed parallel to the sonic log record, and a good agreement appears to exist between the two sets of data (Barron, Larsen, et al., 1989). In the range of porosities observed in Hole $739 \mathrm{C}$ (mostly less than $40 \%$ ), the Raymer-Hunt equation is:

$$
V=(1-\phi)^{2} V m a+\phi V_{f}
$$

where $V=$ bulk sonic velocity in meters per second $(\mathrm{m} / \mathrm{s}), \phi=$ porosity of formations in porosity unit (PU), $V m a=$ sonic velocity in matrix in $\mathrm{m} / \mathrm{s}$, and $V_{f}=$ sonic velocity of the fluid contained in the porosity in $\mathrm{m} / \mathrm{s}$.

Because the general lithology is almost identical in Holes $739 \mathrm{C}$ and 742A and mainly consists of diamictites (Barron, Lar- sen, et al., 1989), the sonic velocity in the matrix has been inferred from the neutron porosity and sonic transit time logs recorded at Site 742A, as proposed by Pelline (1989). The porosity $\phi$, computed from the sonic log, will be called "PHI SON" in the following sections and in the figures.

\section{METHODOLOGY}

As mentioned in the "Introduction," the most advanced actual methods for lithology evaluation from logs consist calculating the normative mineralogy changes of the sedimentary sequences (Herzog et al., 1987). Unfortunately this method may not be applied in this study because it requires geochemical log data such as silicon, iron, calcium, and other elementary components not recorded in the Leg 119 holes. So the methodology used for this study is the standard crossplot technique presented as "facio sequential analysis in complex matrix" by Augier (1980), Mathis (1988), Mathis et al. (1988), and Mathis et al. (1989). The logged sections are divided into logging units on the basis of gradients or of abrupt changes observed on the log records. Most of the logging units in the present study correspond to the main lithologic units, with slight depth differences. Each logging curve was then carefully sampled in order to divide it into thin depth intervals characterized by constant log values. These thin selected depth intervals were named electrobank in accordance with Serra (1979). Each one corresponds to a particular lithology. The thickness of the electrobanks is of the order of $1 \mathrm{~m}$, sometimes more, depending on the thickness of the lithologic layers and on the vertical resolution of the logging tools. Because the sampling rate of the logging tools is about $15 \mathrm{~cm}$, one electrobank averages about 7 log values. The logging parameter values affected by bad hole conditions are systematically discarded, as well as incorrect values resulting from tool failures, so that the electrobanks are as representative as possible of the lithologic changes. It was not possible to process the incorrect logging data for hole size effect because the caliper did not work properly during Leg 119 (Barron, Larsen, et al., 1989). The selected logging parameter values of the electrobanks are plotted in diagrams where standard mineralogic or lithologic poles are already plotted. The lithology of each electrobank is determined by comparing its position with the position of the standard lithologic poles (Augier, 1980). The lithology of an electrobank may also be inferred from a depth interval which exhibits similar log characteristics and which was fully sampled. In order to be consistent with the vocabulary commonly employed by the log-analysts, we will call the lithologic facies derived from logs "lithofacies" in the following sections (Serra, 1985). Two kinds of parameters are used for the final lithologic interpretation: untreated logging parameters and calculated parameters. The untreated logging parameters used in the present study have been described in the preceding chapter. The logging responses are calibrated using physical and chemical parameters measured on samples (Barron, Larsen, et al., 1989; Cranston, chapter 20 , this volume).

Equations of the $M, N$, and $P$ parameters (Serra, 1985; Ellis, 1987; Schlumberger, 1988) are as follows:

$$
\begin{gathered}
M=(\mathrm{DT} f-\mathrm{DT} / \mathrm{RHOB}-\mathrm{RHOB} f) 0.01, \\
N=(\mathrm{NPHI} f-\mathrm{NPHI}) /(\mathrm{RHOB}-\mathrm{RHOB} f), \text { and } \\
P=(\mathrm{NPHI} f-\mathrm{NPHI}) /(\mathrm{DT} f-\mathrm{DT}) 100,
\end{gathered}
$$

where RHOB $f=$ drilling fluid density in $\mathrm{g} / \mathrm{cm}^{3}, \mathrm{NPHI} f=$ drilling fluid neutron porosity in PU, and DT $f=$ traveltime in borehole fluid in $\mu \mathrm{s} / \mathrm{ft}$.

The calculated $M, N$, and $P$ parameters used are almost independent from porosity (Burke et al., 1969). At Hole 738C, the $N$ and $P$ parameters were calculated using the corrected 


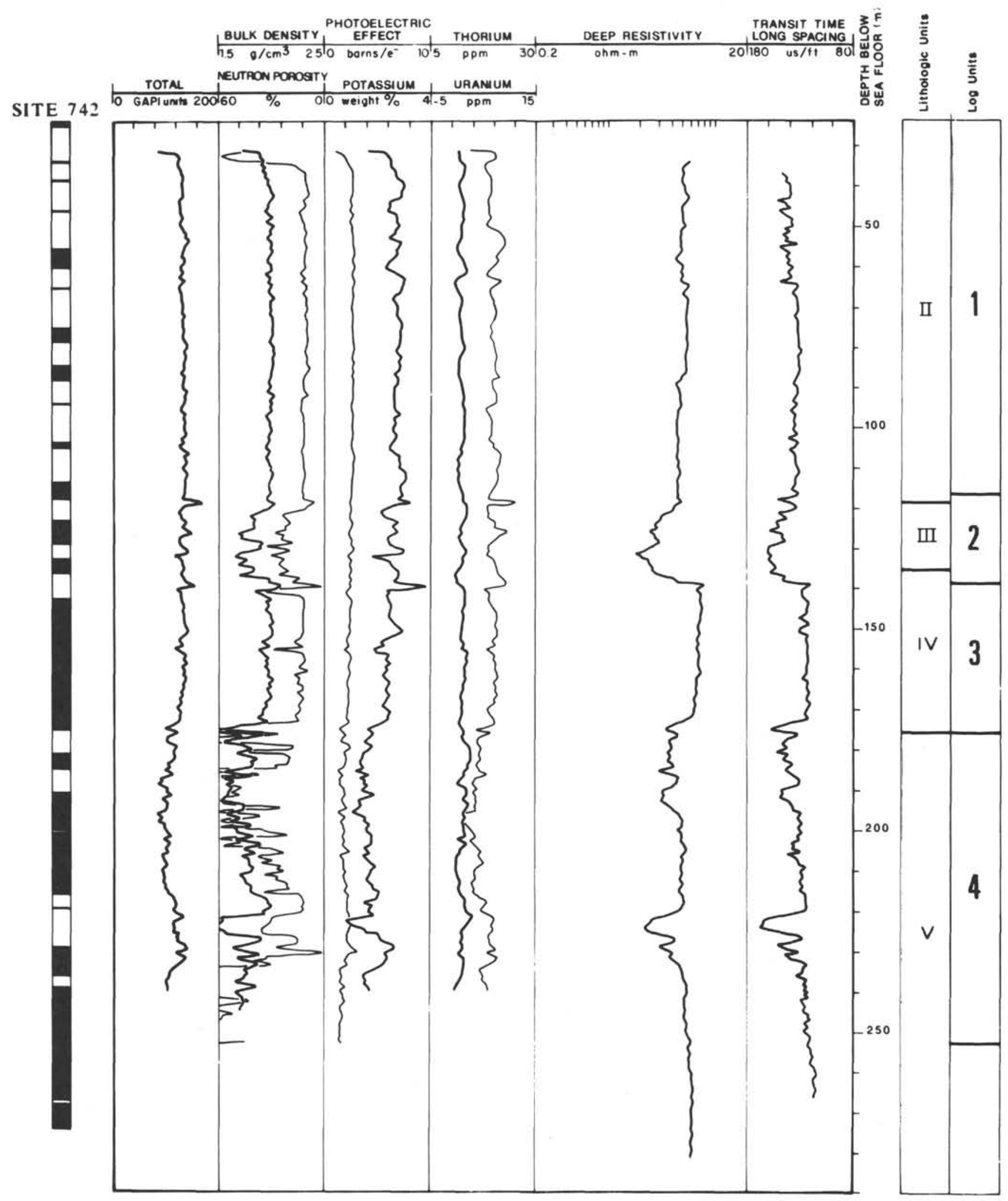

Figure 6. Core recovery, geophysical logs, lithologic units, and logging units in Hole 742A (modified from Barron, Larsen, et al., 1989). The geophysical logs consist of the total natural radioactivity, bulk density, neutron porosity, photoelectric effect, potassium content, thorium content, uranium content, deep resistivity, and long-spacing sonic transit time logs, acquired with the Schlumberger tools described in Ellis, 1987. 


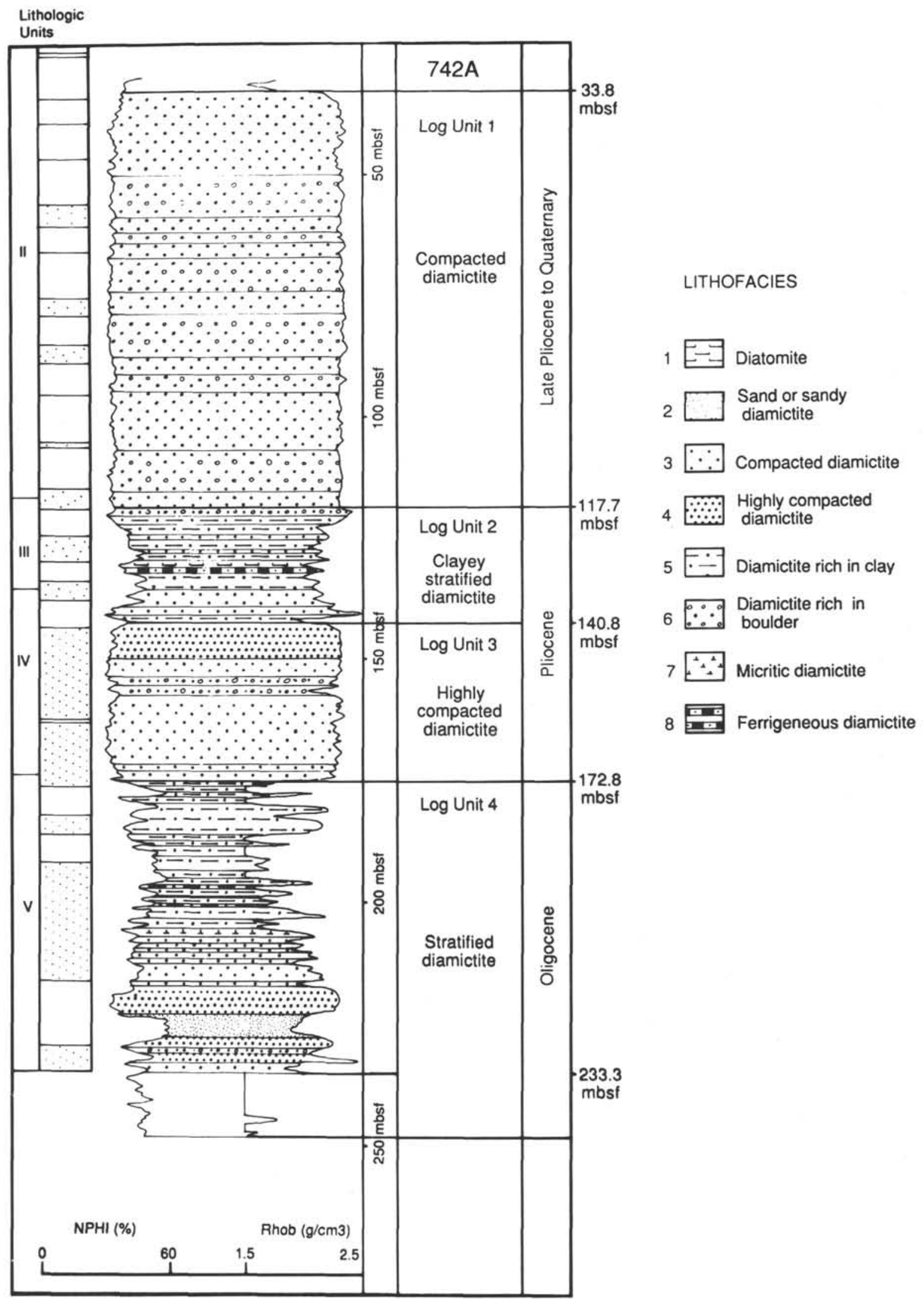

Figure 7. Lithologic units, core recovery, log-inferred lithologic column, and ages in Hole 742A. The log-inferred lithologic column is represented between the neutron porosity $\log$ (NPHI) and the bulk density log (RHOB). The lithologic units and the ages are from Barron, Larsen, et al. (1989). 


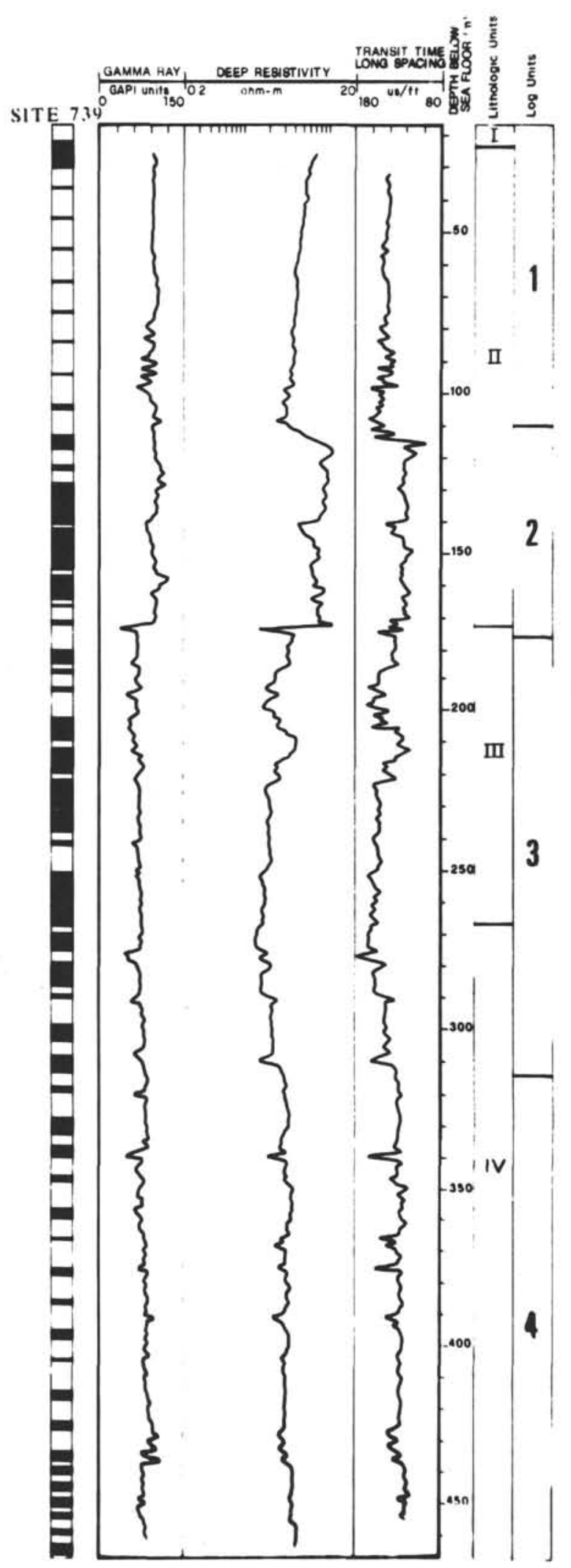

Figure 8. Core recovery, geophysical logs, lithologic units, and logging units in Hole 739C (modified from Barron, Larsen, et al., 1989). The geophysical logs consist of the natural radioactivity, deep resistivity, and long-spacing sonic transit time logs recorded with the Schlumberger tools described in Ellis, 1987.
NPHI and DT parameters for water effect. At Hole 739C, the $N$ and $P$ parameters were calculated using the PHI SON log values and the core bulk density measurements. A given lithology is determined by an iterating process between different lithologic or mineralogic crossplots. The diagrams that we used for the lithology interpretation are standard crossplots commonly used in the oil industry, RHOB-NPHI, RHOB-DT, N-P, PEF-N, PEF-Th/ K, SGR-U, and Th-K (Augier, 1980), but modified for the present study in order to take into account some particularities of the formations encountered, such as their high porosity, which reaches $85 \%$ for some oozes. So, concurrent with the use of the standard crossplots, we will establish the on-core density-porosity crossplots in order to calibrate the log responses for the unknown lithologies, particularly in the high porosity depth intervals. The clay and opal poles, kaolinite-smectite pole (clay K$\mathrm{Sm}$ ), illite-muscovite pole (clay Ill-Mu), and porcellanite pole of the different diagrams correspond to uncompacted shaley and opal formations from all around the world (Table 1) (Augier, 1980; Serra, 1985; Ellis et al., 1988). The pure mineralogical poles are represented in the diagrams by the symbols Ka for kaolinite, $\mathrm{Mu}$ for muscovite, Ill for illite, $\mathrm{Cl}$ for chlorite, Mo for montmorillonite, KF for microcline, Q for pure quartz or pure "sandstone," C for calcite or pure "limestone," and D for dolomite or pure "dolomite." The numbers $10,20,30$, and 40 appearing along the lithologic lines in the RHOB-NPHI, RHOBDT, and density-PHI SON crossplots correspond to $10 \%, 20 \%$, $30 \%$, and $40 \%$ porosity values for pure limestone, sandstone and dolomite lithologies.

\section{RESULTS}

\section{Log-Inferred Lithology in Calcareous Sequences of the Kerguelen Plateau Sites}

\section{Hole $737 B$ (Fig. 3)}

According to the core description the dominant lithology within the logged section (296.5-701.0 mbsf) is essentially composed of calcareous oozes and calcareous claystone with minor content of diatoms and volcanic layers (Barron, Larsen, et al., 1989). The carbonate content increases indeed significantly below $225 \mathrm{mbsf}$ where it becomes the dominant component in lieu of the opal-A in the upper drilled sequence (Bohrmann and Ehrmann, this volume). The density-porosity relationship available for pure calcareous lithology within the range of porosity $0 \%-40 \%$ (Schlumberger, 1988) may not be applied to the complex high-porosity calcareous formations encountered in Hole 737B. A density-porosity crossplot from core measurements allows to establish the general linear relationship for the present high-porosity lithology (Fig. 11). The existence of a linear relationship between density and porosity beyond $40 \%$ of porosity is also shown on the RHOB-DT crossplot (Fig. 12A). This linear relationship corresponds to a regular decay in porosity with depth increasing as a result of the compaction of the calcareous sediments. Because of a saturation effect of the neutron device (Serra, 1985) the neutron porosity do not increase above $60 \%$ (Figs. 12B and 2). However, the bulk density continues to decrease, which makes the RHOB-NPHI relationship not as linear as the density-porosity relationship seen from cores (Fig. 12B). On the RHOB-DT and RHOB-NPHI crossplots (Figs. 12A and $12 \mathrm{~B})$, the plotted values fall between the pole of the clays and the line of the limestone grain density $\left(2.71 \mathrm{~g} / \mathrm{cm}^{3}\right)$, confirming the lithology from cores and suggesting the presence of a significant amount of clay in these sediments. The radioactivity is almost totally related to the potassium content while the contribution from the uranium and thorium content is small, except at the top of the logged section in Hole 737B (Figs. 12C and 12D). Moreover, the RHOB-DT and RHOB-NPHI crossplots (Figs. 


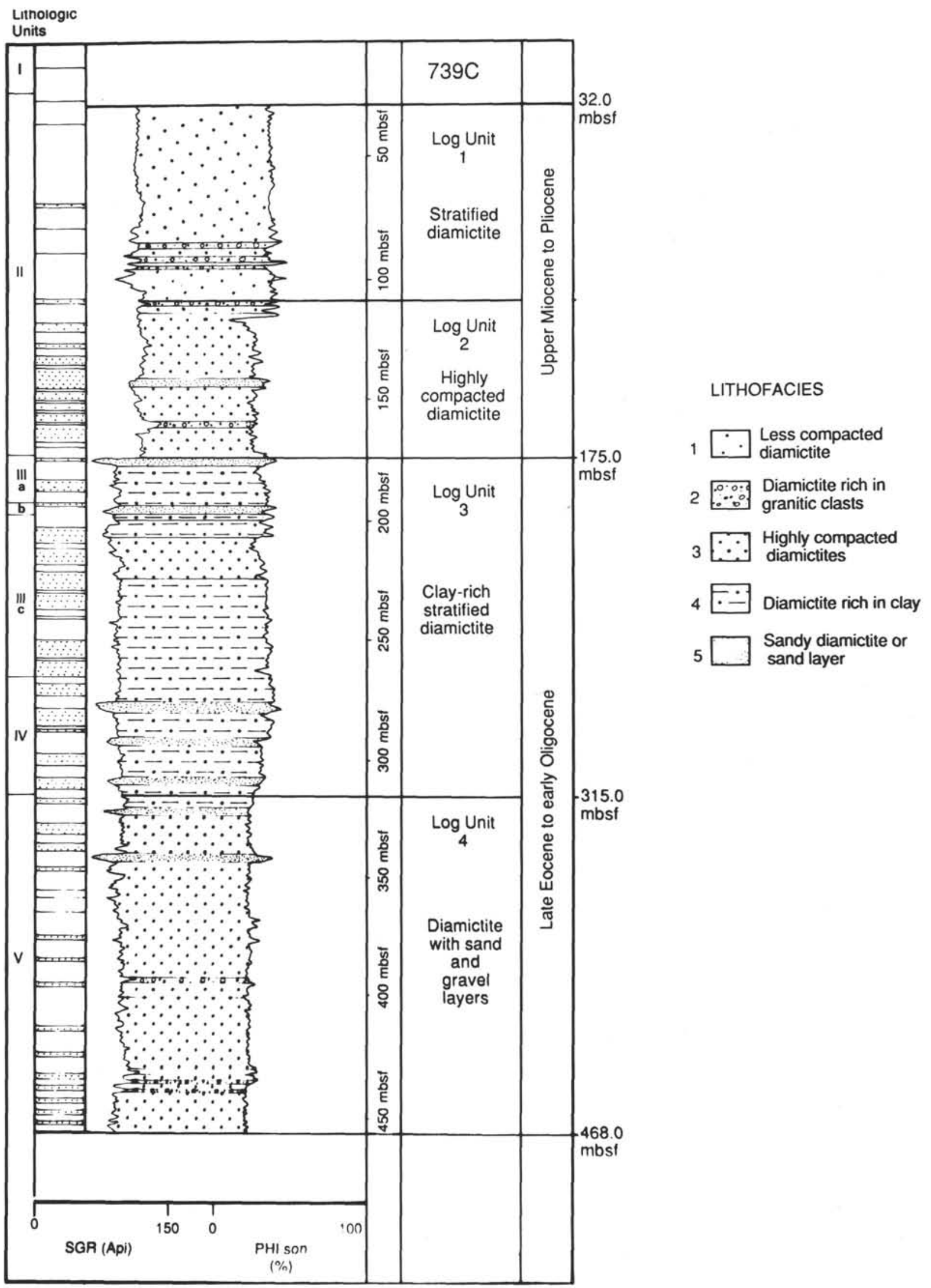

Figure 9. Lithologic units, core recovery, log-inferred lithologic column, and ages in Hole 739C. The log-inferred lithologic column is represented between the natural gamma-ray $\log (\mathrm{GR})$ and the porosity $\log$ (PHI SON) calculated from the long-spacing sonic transit time log using the Raymer-Hunt equation (Raymer et al., 1980). The lithologic units and the ages are from Barron, Larsen, et al. (1989). 


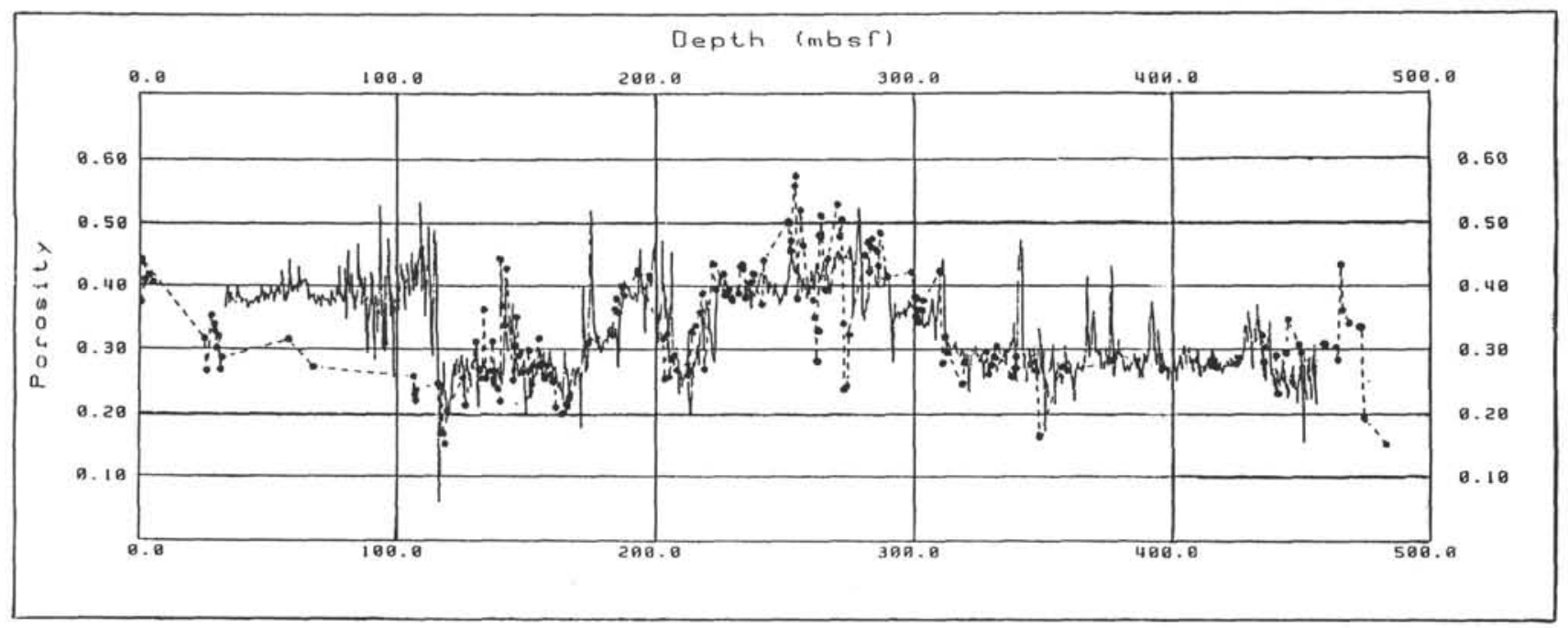

Figure 10. Comparison between in-situ calculated porosities (NPHI SON) and porosities measured on core. The in-situ calculated porosities were computed by Pelline (1989) using the Raymer-Hunt equation (Raymer et al. 1980). The matrix velocity of the diamictites was obtained by comparison with that known for the diamictites of Hole 742A.

Table 1. Standard lithologic and mineralogic poles.

\begin{tabular}{|c|c|c|c|c|c|c|c|c|c|c|c|c|}
\hline & $\begin{array}{l}\text { RHOB } \\
\left(\mathrm{g} / \mathrm{cm}^{3}\right)\end{array}$ & $\begin{array}{l}\text { NPHI } \\
\text { (PU) }\end{array}$ & $\underset{(\mu \mathrm{S} / \mathrm{ft})}{\mathrm{DT}}$ & $\begin{array}{c}\text { GR } \\
\text { (API) }\end{array}$ & $\begin{array}{l}\text { PEF } \\
\text { (b/e) }\end{array}$ & $\underset{(\mathrm{ppm})}{\mathrm{U}}$ & $\begin{array}{c}\text { Th } \\
\text { (ppm) }\end{array}$ & $\underset{(\%)}{K}$ & $\mathrm{Th} / \mathrm{K}$ & M & $\mathrm{N}$ & $\mathbf{P}$ \\
\hline \multicolumn{13}{|l|}{ Standard lithologic poles } \\
\hline Quartz 0 (Q0) & 2.65 & -0.02 & 55.5 & & 1.81 & 0.7 & 2 & 0 & & 0.80909091 & 0.61818182 & 0.76404494 \\
\hline Quartz 10 (Q10) & 2.48 & 0.08 & 69 & & & & & & & 0.81081081 & 0.62162162 & 0.76666667 \\
\hline Quartz 20 (Q20) & 2.3 & 0.18 & 82.5 & & & & & & & 0.81923077 & 0.63076923 & 0.76995305 \\
\hline Quartz 30 (Q30) & 2.15 & 0.28 & 96.5 & & & & & & & 0.80434783 & 0.62608696 & 0.77837838 \\
\hline Quartz 40 (Q40) & 1.97 & 0.38 & 109 & & & & & & & 0.82474227 & 0.63917526 & 0.775 \\
\hline Calcite $0(\mathrm{C} 0)$ & 2.71 & 0 & 48 & & 5.08 & & & & & 0.8245614 & 0.58479532 & 0.70921986 \\
\hline Calcite $10(\mathrm{C} 10)$ & 2.54 & 0.1 & 62 & & & & & & & 0.82467532 & 0.58441558 & 0.70866142 \\
\hline Calcite 20 (C20) & 2.36 & 0.2 & 76 & & & & & & & 0.83088235 & 0.58823529 & 0.7079646 \\
\hline Calcite 30 (C30) & 2.2 & 0.3 & 89 & & & & & & & 0.83333333 & 0.58333333 & 0.7 \\
\hline Calcite 40 (C40) & 2.02 & 0.4 & 105 & & & & & & & 0.82352941 & 0.58823529 & 0.71428571 \\
\hline Dolomite 0 (D0) & 2.88 & 0.01 & 43.5 & & 3.14 & & & & & 0.77393617 & 0.52659574 & 0.68041237 \\
\hline Dolomite 10 (D10) & 2.69 & 0.115 & 58 & & & & & & & 0.77514793 & 0.52366864 & 0.67557252 \\
\hline Dolomite 20 (D20) & 2.51 & 0.21 & 72 & & & & & & & 0.77483444 & 0.52317881 & 0.67521368 \\
\hline Dolomite 30 (D30) & 2.32 & 0.31 & 87 & & & & & & & 0.77272727 & 0.52272727 & 0.67647059 \\
\hline Dolomite 40 (D40) & 2.13 & 0.41 & 101 & & & & & & & 0.77876106 & 0.52212389 & 0.67045455 \\
\hline Clay $\mathrm{Ka}-\mathrm{Sm}$ & 2.32 & 0.412 & 133 & & 1.83 & & & & & 0.42424242 & 0.44545455 & 1.05 \\
\hline Clay III & 2.38 & 0.45 & 106 & & 3.45 & & & & & 0.60144928 & 0.39855072 & 0.6626506 \\
\hline Clay $\mathrm{Ka}-\mathrm{Fe}$ & 2.67 & 0.37 & 112 & & & & & & & 0.46107784 & 0.37724551 & 0.81818182 \\
\hline Porcellanite & 1.55 & 0.465 & 162.5 & & 1.15 & & & & & 0.48181818 & 0.97272727 & 2.01886792 \\
\hline \multicolumn{13}{|l|}{ Standard mineralogic poles } \\
\hline Opal & 2.16 & 0.2 & 58 & & 1.75 & & & & & 1.12931034 & 0.68965517 & 0.61068702 \\
\hline K-feldspar (KF) & 2.56 & -0.02 & 56 & 220 & 2.86 & & 12 & 16 & 0.62 & 0.8525641 & 0.65384615 & 0.76691729 \\
\hline Chlorite $(\mathrm{Cl})$ & 2.77 & 0.52 & & 220 & 6.3 & & & & 19 & 1.06779661 & 0.27118644 & 0.25396825 \\
\hline Muscovite (Mu) & 2.93 & 0.3 & 65 & 270 & 2.4 & & & & 24 & 0.64248705 & 0.3626943 & 0.56451613 \\
\hline Biotite & 3.13 & 0.3 & 65 & 280 & 6.27 & & & & & 0.58215962 & 0.3286385 & 0.56451613 \\
\hline Kaolinite (Ka) & 2.42 & 0.37 & 133 & 105 & 1.83 & & 18.5 & 0.5 & 20 & 0.3943662 & 0.44366197 & 1.125 \\
\hline Illite (III) & 2.53 & 0.3 & 106 & 280 & 3.45 & & 22 & 6.9 & 2.5 & 0.54248366 & 0.45751634 & 0.84337349 \\
\hline Complex clay (Is) & & & & & 4.3 & & & & 6 & -1.89 & -1 & 0.52910053 \\
\hline Montmorillonite (Mo) & 5 & 0.44 & & 180 & 2.04 & & 19 & 1.5 & 6 & 1.6875 & 0.5 & 0.2962963 \\
\hline Pyrite & 5 & -0.03 & 392 & & & & & & & -0.5075 & 0.2575 & -0.5073892 \\
\hline
\end{tabular}

Note: After Augier (1980), Serra (1985), and Ellis et al. (1988).

$12 \mathrm{~A}$ and $12 \mathrm{~B}$ ) show that the presence of potassium is not related to the existence of non-clay minerals, such as $\mathrm{K}$-feldspar or other non-clay-rich potassium minerals, so the total radioactivity measurement appears as a good clay indicator in this hole. Because no analyses are available for the clay minerals at Site $737 \mathrm{~B}$, the X-ray analyses provided by Ehrmann and Bohrmann and Ehrmann (both this volume), for similar calcareous forma- tions encountered at Site $738 \mathrm{C}$, were used in order to calibrate the SGR log in terms of percentage of clay content. Approximately 7 GAPI units were found to correspond to a clay content representing $10 \%$ of the dry bulk in Hole $738 \mathrm{C}$ (Fig. 4). The thorium-potassium plots shown in Bateman (1985) and Schlumberger (1988), and employed at Hole 737B, suggest that illite and montmorillonite are the dominant clay minerals. (Fig. 12D). 


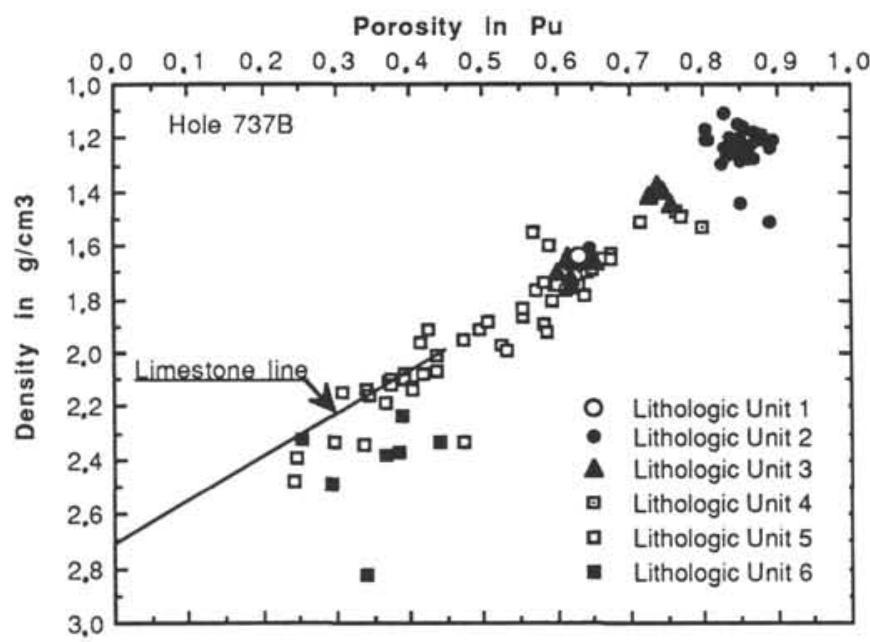

Figure 11. Density-porosity crossplot from core measurements in Hole 737B. The densities, porosities, and the lithologic units are from Barron, Larsen, et al. (1989).

The sedimentary formations can be differentiated into 9 lithofacies in Hole 737B; these nine lithofacies are spread over six major logging units (Fig. 3).

\section{Logging Unit 1 (296.5-318.5 mbsf)}

This logging unit corresponds to the base of lithologic Unit 3 and to the top of lithologic Unit 4. The density-porosity crossplot from core measurements within lithologic Unit 3 (Fig. 11) allows to differentiate two groups of plotted data, one group with densities of about $1.4 \mathrm{~g} / \mathrm{cm}^{3}$ and porosities of $75 \%$ which correspond to diatom nannofossil ooze, and one group with densities of $1.7 \mathrm{~g} / \mathrm{cm}^{3}$ and porosities of $60 \%$ which corresponds to volcanic sands or diatom nannofossil ooze mixed with volcanic sands. Comparatively to the core observations, alternations of relatively high and low density electrobanks, close to the core density values, are seen on the logging curves (Fig. 2), allowing to extrapolate the previous lithologies within the non recovered intervals (Fig. 3). Within logging Unit 1 one lithofacies (lithofacies 1) with relatively high bulk density and high radioactivity values and other lithofacies (lithofacies 2) with relatively low bulk density and low radioactivity values can be distinguished (Figs. 12E and 2). The high radioactivity values, greater than 120 GAPI units, match a high uranium and potassium content and within a Th-K diagram (Fig. 12F) are close to the field of K-feldspar. This is in agreement with the volcaniclastic layers with a significant content of $\mathrm{K}$-feldspar, as found in the volcanic sands identified from cores (Morche et al., this volume). The low radioactivity values match the general calcareous lithology. They fall in the high-porosity region $(65 \%)$ of the RHOB-NPHI crossplot, thus indicating very uncompacted oozes. According to the K-Th crossplot, the uncompacted ooze appears to contain mainly montmorillonite as clay type (Fig. $12 \mathrm{~F})$. The presence of montmorillonite within this depth interval is well correlated with a relatively high carbonate content observed by Bohrmann and Ehrmann (this volume).

The following logging units $(2,3,4$, and 5$)$ belong to the same lithologic Unit 5 that is described as a calcareous claystone (Barron, Larsen et al., 1989).

\section{Logging Unit 2 (318.5-350.0 mbsf)}

Logging Unit 2 is characterized by a relatively high carbonate content ( $40 \%$ of the dry bulk), (Bohrmann and Ehrmann, this volume). According to the physical properties measurements completed on cores, this lithologic unit appears as a low-density $\left(1.5 \mathrm{~g} / \mathrm{cm}^{3}\right)$, high-porosity $(70 \%)$ unit (Fig. 11). The geophysical logs within this depth interval, although underestimating a little the density values $\left(1.3 \mathrm{~g} / \mathrm{cm}^{3}\right)$, agree with the core measurements (Fig. 12B). So the calcareous claystone lithology may be extrapolated to the few nonrecovered intervals of this logging unit. On the basis of the low rate of radioactivity of this formation (20 GAPI units), one can roughly estimate the clay content to a maximum of $28.5 \%$ of the dry bulk. However, adding here $40 \%$ carbonate content plus $28.5 \%$ clay content, $100 \%$ of dry bulk is not reached, so the remaining components have probably to be found in an unknown amount of feldspar and zeolite clinoptilolite as detected by Borhmann and Ehrmann (this volume). Finally, logging Unit 2 is represented totally by lithofacies 3 which matches uncemented and clayey calcareous oozes (Fig. 3).

\section{Logging Unit 3 (350.0-431.5 mbsf)}

Within logging Unit 3 the radioactivity level is significantly higher than within logging Unit 2 , with a mean value ranging around 27 GAPI on the entire unit (Fig. 2). Applying the transform defined above to the SGR log, a clay content of $38.5 \%$ of the dry bulk is estimated within this unit. The higher clay content computed from logs, between 350.0 and $431.5 \mathrm{mbsf}$, is well correlated with the low in the carbonate content shown by Bohrmann and Ehrmann (this volume), thus emphasizing a clear detrital influence confirmed by the presence of illite (Chamley, 1989), as clearly shown on the Th-K crossplot (Fig. 13A). In logging Unit 3, the core bulk densities range from 1.55 to 1.8 $\mathrm{g} / \mathrm{cm}^{3}$ whereas the porosities range from $67.5 \%$ to $56.6 \%$. Corrected NPHI values for the neutron saturation effect would almost fall within the same area than the core data in the densityporosity crossplot (Fig. 12B). So the general lithology defined from the core (calcareous claystone) may be used for the nonrecovered intervals, which are particularly frequent in this depth interval. However, the term "uncemented and very clayey calcareous ooze" will be employed for the major lithofacies (lithofacies 4) instead of calcareous claystone, to take into account the high porosity and the relatively high clay content of these formations. A 2-m-thick layer with relatively low values of porosity and sonic transit time and relative high values of density occurs at the lower part of logging Unit 3 (426.5-427.5 mbsf) (Fig. 2). On the RHOB-DT and RHOB-NPHI crossplots (Fig. 13B and $13 \mathrm{C})$, the plotted data from this layers are shifted toward the porcellanite pole, indicating the presence of chert layers (lithofacies 5). The sonic velocity and resistivity values are increasing significantly below 375 mbsf without appreciable porosity decrease and density increase. It suggests, however, a beginning of lithification of the oozes in the lower part of the unit (Fig. 2), following the same diagenetic processes described by Moore (1989).

\section{Logging Unit 4 (431.5-517.5 mbsf)}

Compared to the previous logging unit, a distinct decrease in radioactivity level is noted in this unit, the SGR log indicates a decay from 25-30 GAPI to 15-20 GAPI between the two units (Fig. 2). This radioactivity rate would be related to a maximum clay content of about $20 \%$ of the dry bulk. The decrease in clay content within logging Unit 4 occurs concurrently with a significant increase of the carbonate content, up to a maximum of $80 \%$ of the dry bulk (Bohrmann and Ehrmann, this volume). Thus, the mineralogic composition of logging Unit 4 appears very similar to that of logging Unit 2 . The main difference between the two units is a difference of compaction which is indicated by lower porosities in logging Unit 4 (Fig. 2). Also the nature of the clays appears slightly different from that of logging Unit 2, according to the Th-K crossplot, the plotted data are mostly located in the illite field (Fig. 13D). The lithofacies of 


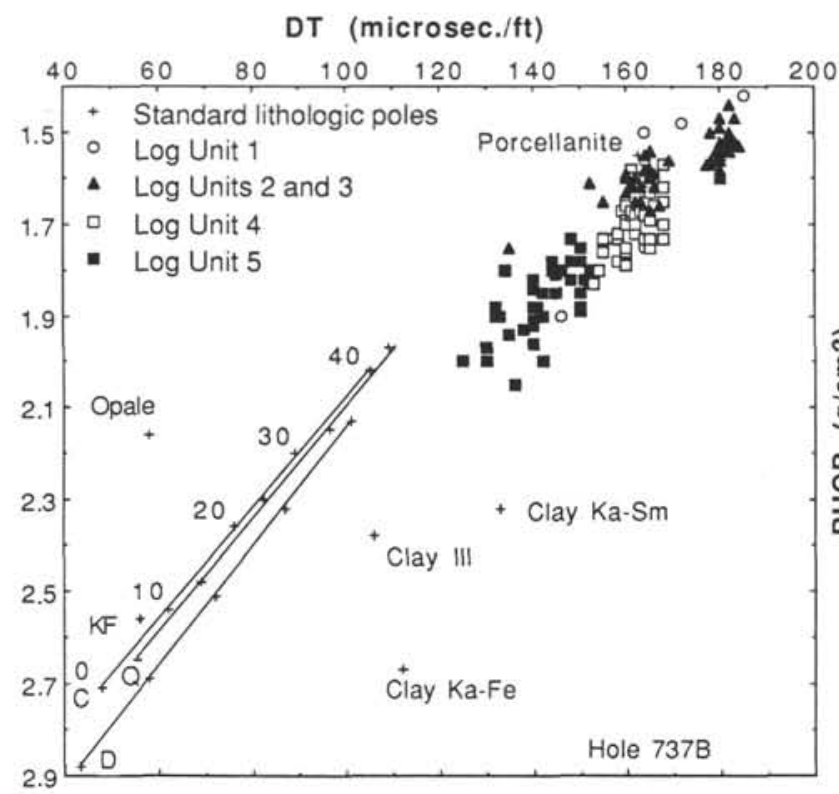

A

$U(\mathrm{ppm})$

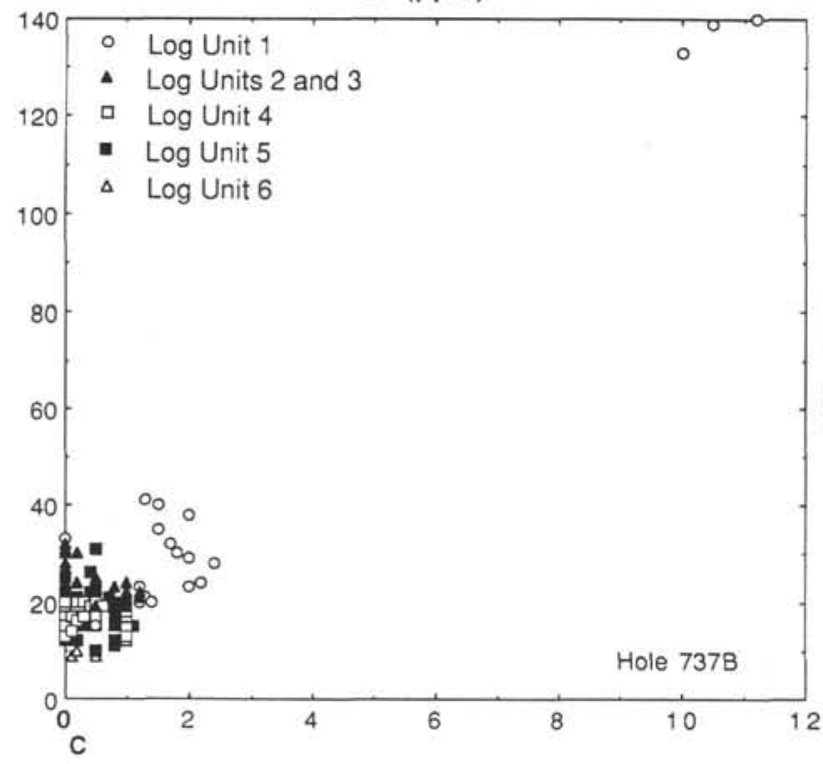

NPHI (pu)

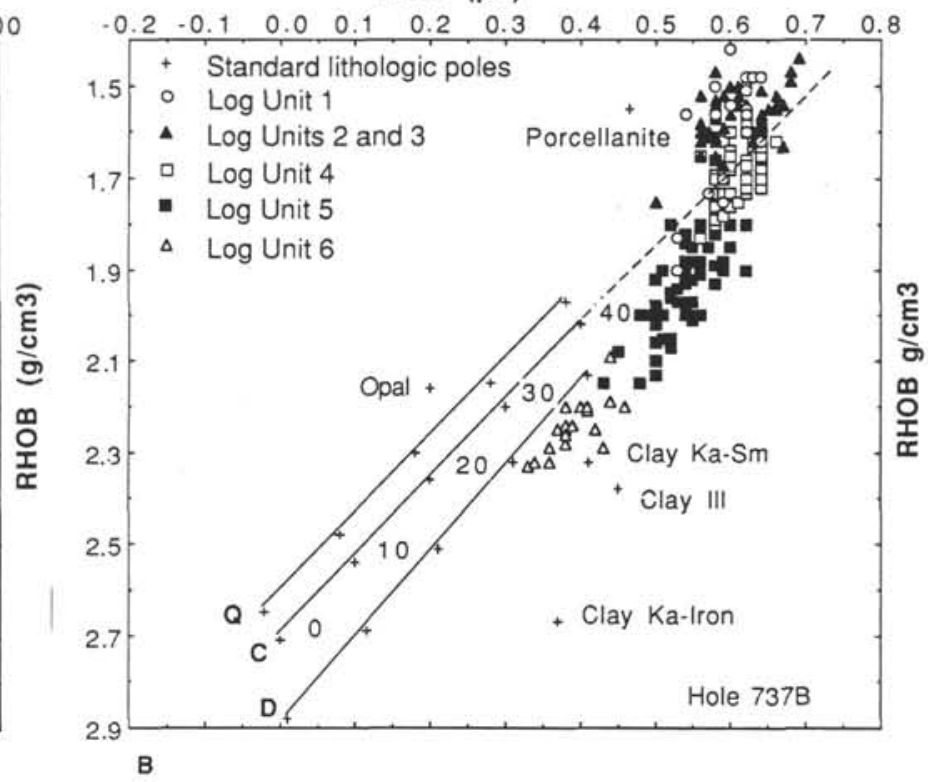

K $(\%)$

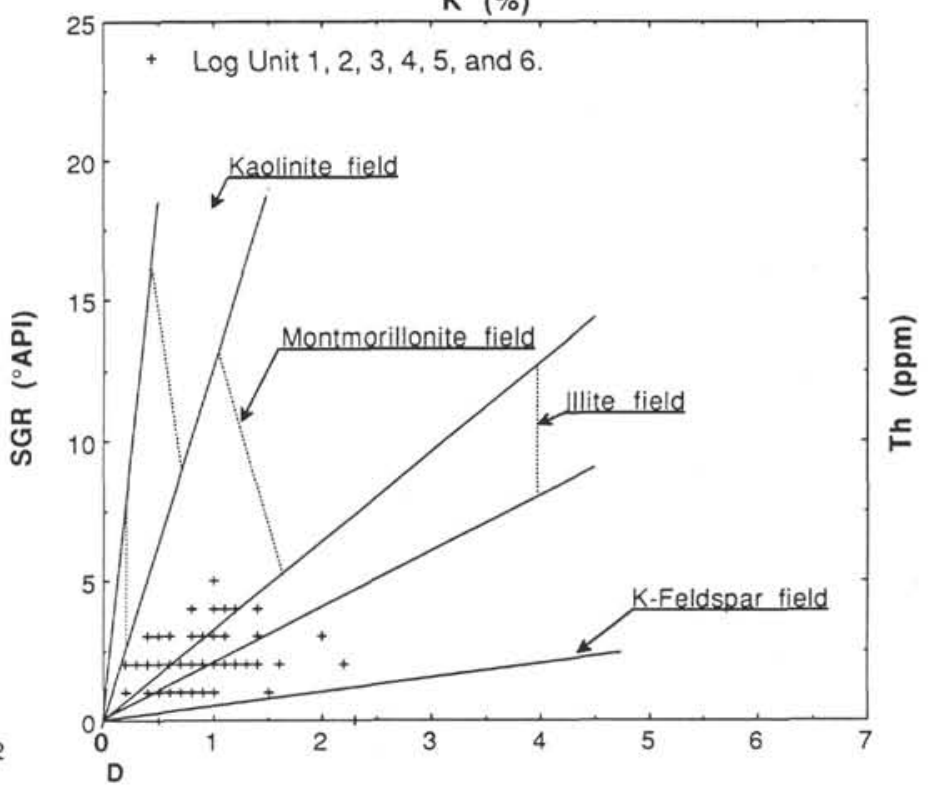

Figure 12. Lithological and mineralogical crossplots in Hole 737B. The crossplots were used by Schlumberger (1988) and Mathis (1988). The mineralogic and lithologic poles and fields are from Augier (1980), Serra (1985), and Ellis et al. (1988). A. RHOB-DT crossplot for the entire logged section. B. RHOB-NPHI crossplot for the entire logged section. C. SGR-U crossplot for the entire logged section. D. Th-K crossplot for the entire logged section. E. SGR-U crossplot for logging Unit 1. F. Th-K crossplot for logging Unit 1.

this unit is lithofacies 6 which is called moderately cemented clayey calcareous ooze. As for the previous units, the comparison between the density-porosity crossplot from core and the RHOB-NPHI crossplot allow us to extrapolate the combined lithology from core and logs to the few nonrecovered intervals.

\section{Logging Unit 5 (517.5-646.5 mbsf)}

Logging Unit 5 is characterized by a regular decay in the porosity values, from $64 \%$ at the top to $42 \%$ at the bottom of the unit (Fig. 2), according to the neutron measurements. The oncore porosity measurements agree also with a porosity decay of about $20 \%$, from the top to the base of the unit, and with porosity values measured, ranging from $50 \%$ to $30 \%$ (Fig. 11).
The $10 \%$ shift between core and log measurements may be explained by the clay "bound-water" content which is seen as porosity by the neutron device (Ellis, 1987). Because the log measurements appear to be relatively consistent with the on-core measurements, the calcareous claystone lithology may be extended within the few nonrecovered intervals. The decay in porosity in the calcareous claystone allows a definition of two lithofacies corresponding to the transition from moderately cemented and very clayey calcareous oozes (lithofacies 7) to weakly cemented limestones (lithofacies 8) (Fig. 3). According to the SGR log, the uppermost part of the unit, from 517.0 to 550.0 mbsf, is corresponding to a clay-rich ooze (lithofacies 7) with a maximum of $27 \%$ clay content of the dry bulk. This clay-rich 
U (ppm)

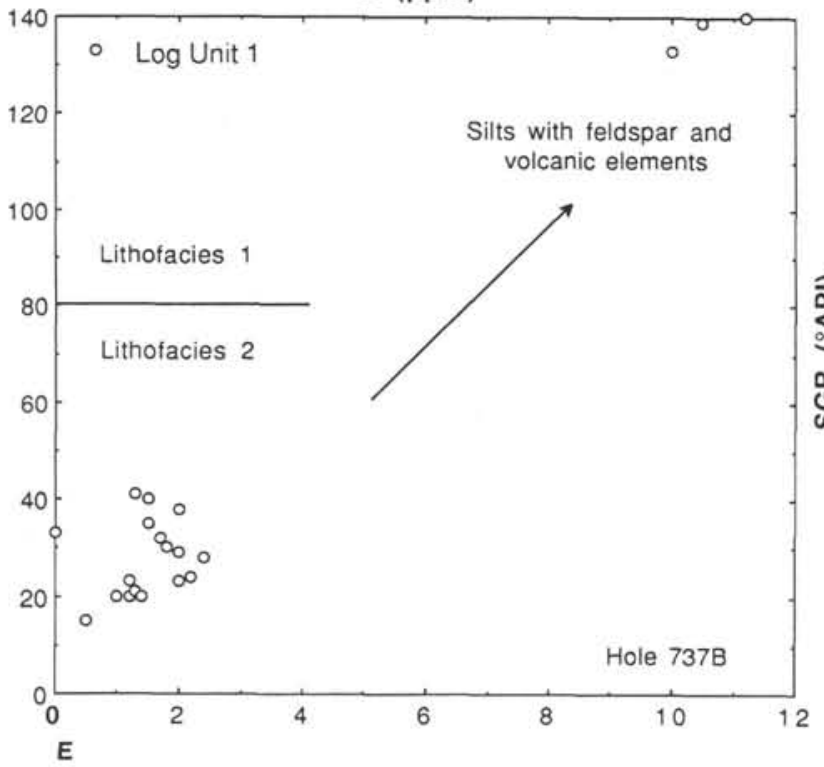

Figure 12 (continued).

lithofacies is well correlated with a clear decrease in carbonate content observed by Bohrmann and Ehrmann (this volume). The lowermost part of the unit appears to be less clayey than the upper part, which is also in good agreement with the higher carbonate content observed by Bohrmann and Ehrmann (this volume). As for the preceding unit, the clay composition appears mainly as illite type (Fig. 13E).

\section{Logging Unit 6 (646.5-701.0 mbsf)}

This unit corresponds to the base of lithologic Unit 5 (calcareous claystone) and to the top of lithologic Unit 6 (clayey limestone). The main characteristics of this Unit, observed from the $\log$ records, are an abrupt decrease in porosity from $58 \%$ to $46 \%$, and an abrupt increase in bulk density from 2.0 to 2.2 $\mathrm{g} / \mathrm{cm}^{3}$ at the top of the unit (Fig. 2). A significant increase in bulk density and decrease in porosity is also observed from cores with the same shift between core and log measurements (Fig. 11). Unlike the preceding high-porosity logging units, the density-porosity relationship proposed by Schlumberger (1988) may be applied to the sediments of logging Unit 6 . On the RHOB-NPHI crossplot, the plotted data of Unit 6 fall between the line of the limestone and the pole of the clays, confirming the term clayey limestone employed in the core descriptions (Fig. 12B). The RHOB-NPHI crossplot and the consistency between core and log measurements in the recovered intervals allow to extrapolate the clayey limestone to the nonrecovered intervals (lithofacies 9), particularly between the top of the unit and $675.0 \mathrm{mbsf}$ where the recovery is particularly poor. The increase with depth of the radioactivity rate from 10 to 25 API suggests an increase in clay content from the top to the base of the Unit. The plotted data of the Th-K diagram for this unit fall mostly within the montmorillonite field (Fig. 13F).

\section{Hole $738 C$ (Fig. 5)}

In Hole $738 \mathrm{C}$, the geophysical logs allow a definition of three major logging units clearly identifiable on the RHOBNPHI and RHOB-DT crossplots (Figs. 14A and 14B). In the present study, eight lithofacies are defined from both core and log information, within these three logging units. The core description indicates that the formations encountered within the

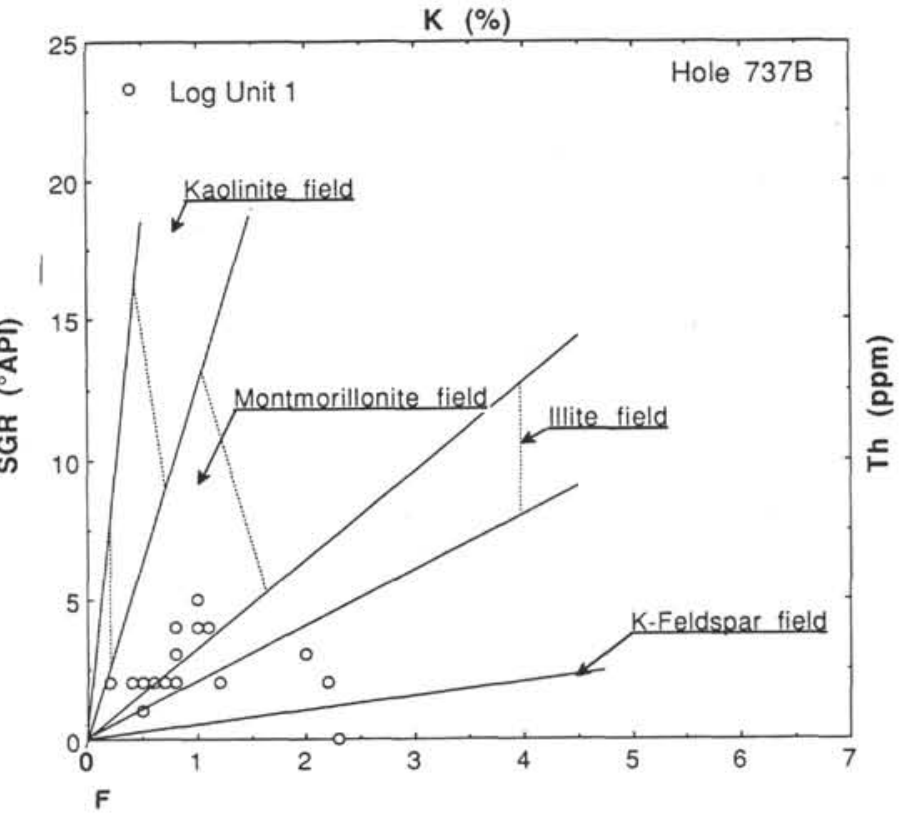

logged section consist mainly of a pure carbonate sequence of calcareous ooze, chalk, and limestone (Barron, Larsen, et al., 1989). Indeed, the carbonate content measured by Hermann (this volume) is close to $85 \%$ on the entire logged interval. However, the density-porosity crossplot from the core shows that the laboratory density measurements are probably overestimated because the plotted data fall below and not on the limestone line (Fig. 15). It also shows that it is possible to extend the linear relationship between density and porosity above $45 \%$ of porosity. In the RHOB-NPHI and RHOB-DT crossplots, the plotted values for the logged interval (113.0-455.0 mbsf) were shifted horizontally toward the limestone grain density line in order to correct them for water effect (Figs. 14A and 14B). The correction applied to the original NPHI values is $-0.08 \mathrm{~g} / \mathrm{cm}^{3}$ and the correction applied to the original DT values is $-20 \mu \mathrm{s} / \mathrm{ft}$. The location of the plotted data from logging Unit 1 , slightly above the line of the limestone, in the RHOB-NPHI crossplot is due to the saturation effect of the neutron device. The PEF values increase downhole from 2.5 barns/electron (b/e) at the top of the logged section to $5 \mathrm{~b} / \mathrm{e}$ at the bottom of the logged section (Fig. 4). The PEF factor of water is $0.358 \mathrm{~b} / \mathrm{e}$ whereas the calcite PEF factor is $5.084 \mathrm{~b} / \mathrm{e}$ (Lamont-Doherty Borehole Research Group, 1988), so the decrease of the PEF values results from the progressive loss of water with increasing depth in the calcareous sequence. The level of radioactivity is very low in Hole $738 \mathrm{C}$; the gamma-ray record never exceeds 25 GAPI units, and the mean level of radioactivity usually ranges between 5 and 10 GAPI units (Figs. 4 and 14C). The low radioactivity rate of the formations in this hole suggests that they contain almost no Th, $\mathrm{K}$, and $\mathrm{U}$, and thus, almost no clay, confirming the pure carbonate sequence. The paucity of clay in Hole $738 \mathrm{C}$, suggested by the SGR log, is in good agreement with the clay determination by Ehrmann and Bohrmann (this volume). The difference in clay content between Sites 737 and 738 is clearly shown by comparing the lithologic crossplots from both sites (RHOB-NPHI and RHOB-DT; Figs. 12A, 12B, 14A, and 14B).

\section{Logging Unit 1 (113.0-250.0 mbsf)}

The depth interval 113.0-250.0 mbsf defined for logging Unit 1 almost fits with the depth interval of lithologic Unit 4 

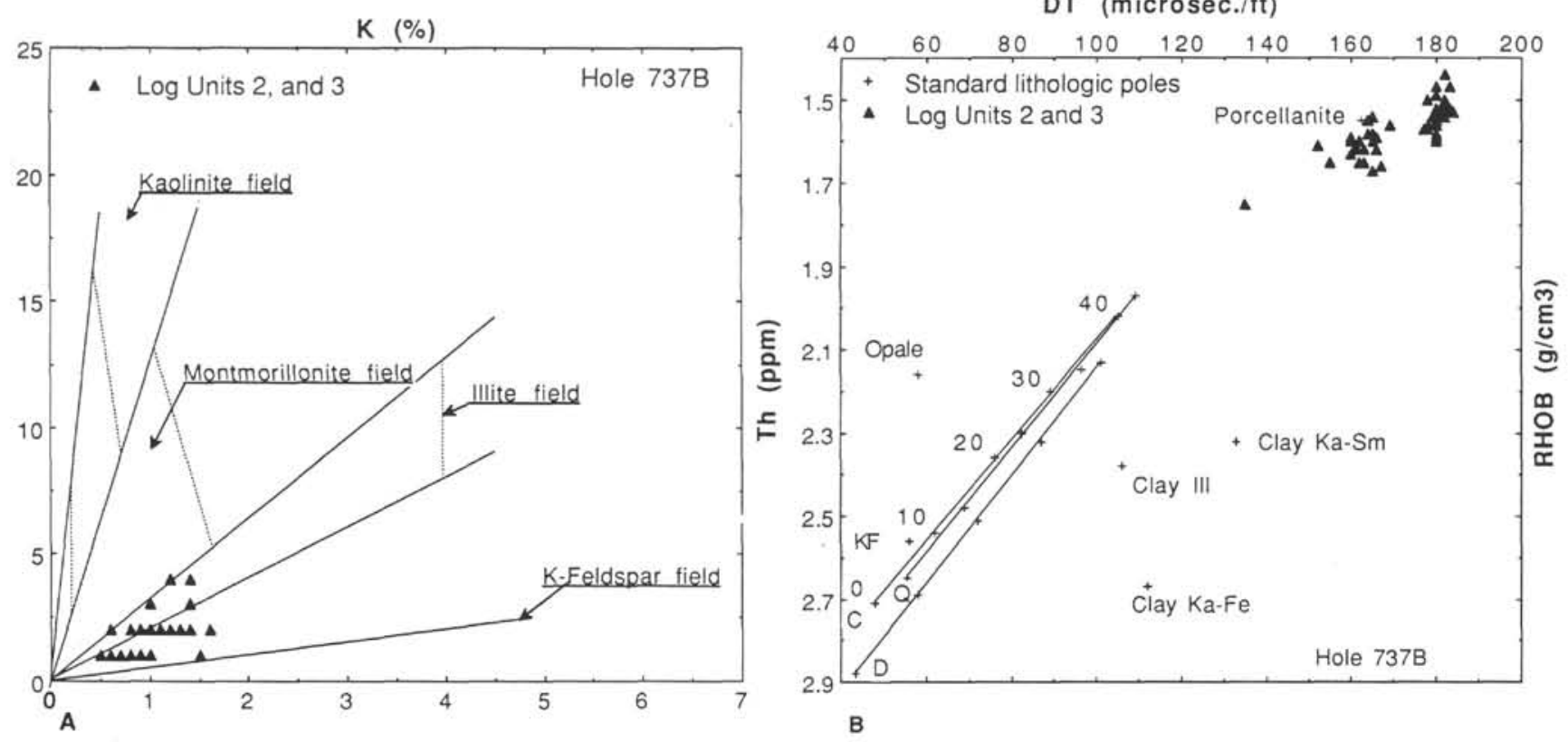

$\mathrm{NPHI}$ (pu)
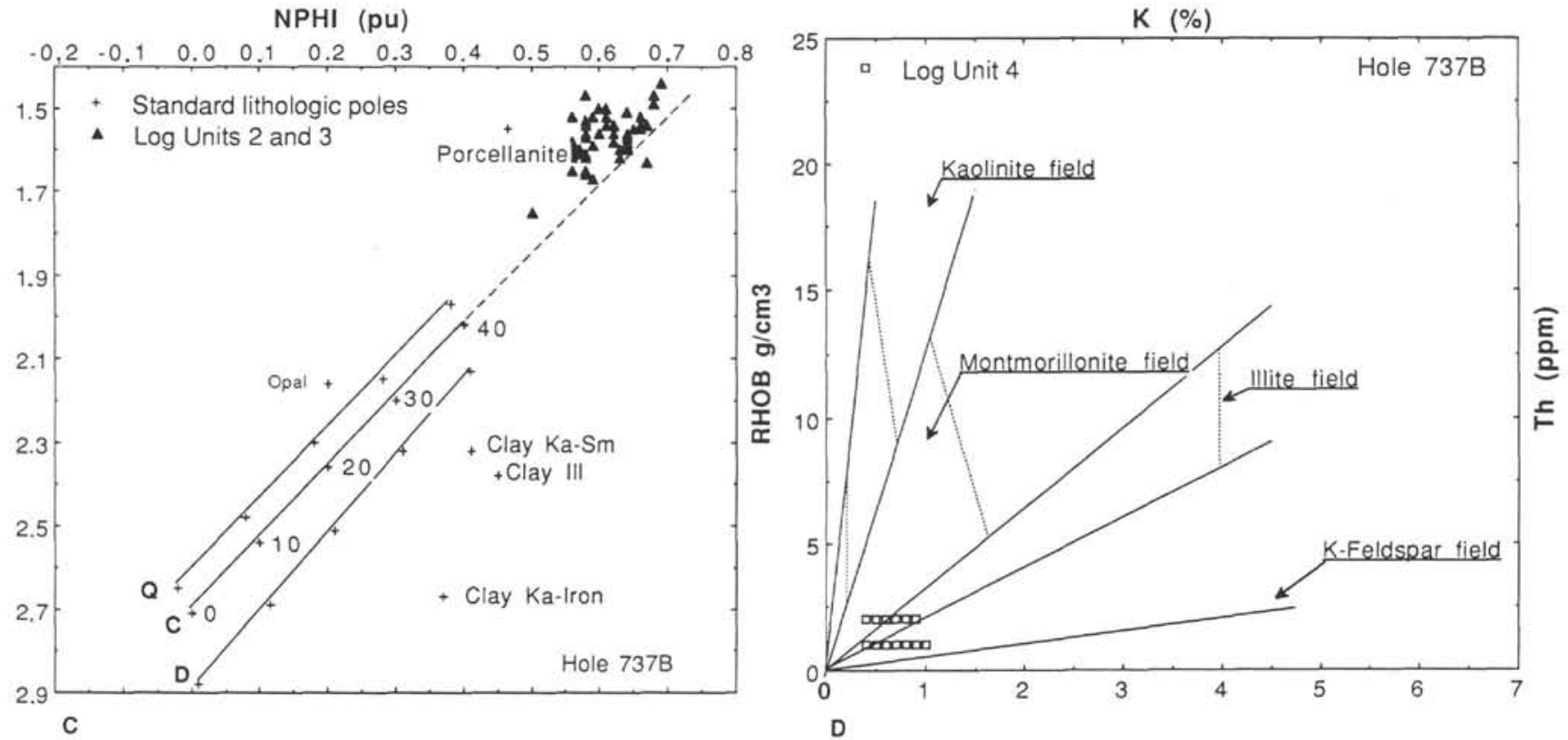

Figure 13. Lithological and mineralogical crossplots in Hole 737B. The crossplots were used by Schlumberger (1988) and Mathis (1988). The mineralogic and lithologic poles and fields are from Augier (1980), Serra (1985), and Ellis et al. (1988). A. Th-K crossplot for logging Units 2 and 3. B. RHOB-DT crossplot for logging Units 2 and 3. C. RHOB-NPHI crossplot for logging Units 2 and 3. D. Th-K crossplot for logging Unit 4. E. Th-K crossplot for logging Unit 5. F. Th-K crossplot for logging Unit 6.

(120.8-254.4), which is described as calcareous nannofossil ooze and chalk. The porosities of this interval are underestimated by the neutron device, which reads porosity values about $10 \%$ lower than the predicted porosities for limestones (Fig. 14A). Taking into account this porosity overestimation, the RHOB-NPHI and RHOB-DT plots (Figs. 14A and 14B) for logging Unit 1 show that the lithology mainly consists of a highly porous $(45 \%$ to $55 \%$ ) calcareous sequence, which matches the oozes described from the cores. Some less porous electrobanks are thought to correspond to chalk layers. Two lithofacies are defined according to the degree of consolidation of the calcareous sediments. Lithofacies 1 is the highly porous calcareous ooze of the top of the unit, whereas lithofacies 2 , which is termed calcareous ooze and chalk, is the weakly cemented ooze, mostly encountered at the base of unit (Fig. 4). The lowermost part of the logging unit (180.0-250.0 mbsf) was almost not recovered by coring, but the uniformity of the lithologic log values on the entire Unit 1 suggests that no major lithologic change occurs within this depth interval (Fig. 4). However, a slight increase in density, resistivity, and sonic velocity with increasing depth, is observed in this logging unit (Fig. 4). It indicates that more chalk layers occur in the lowermost part of the unit. This conclusion is not confirmed by an increase of the carbonate content toward the base of the logging unit (Bohrmann and Ehrmann, this volume), but the carbonate content estimation is based only on few samples within this unit, and the consolidated carbonate-rich chalk layers were 

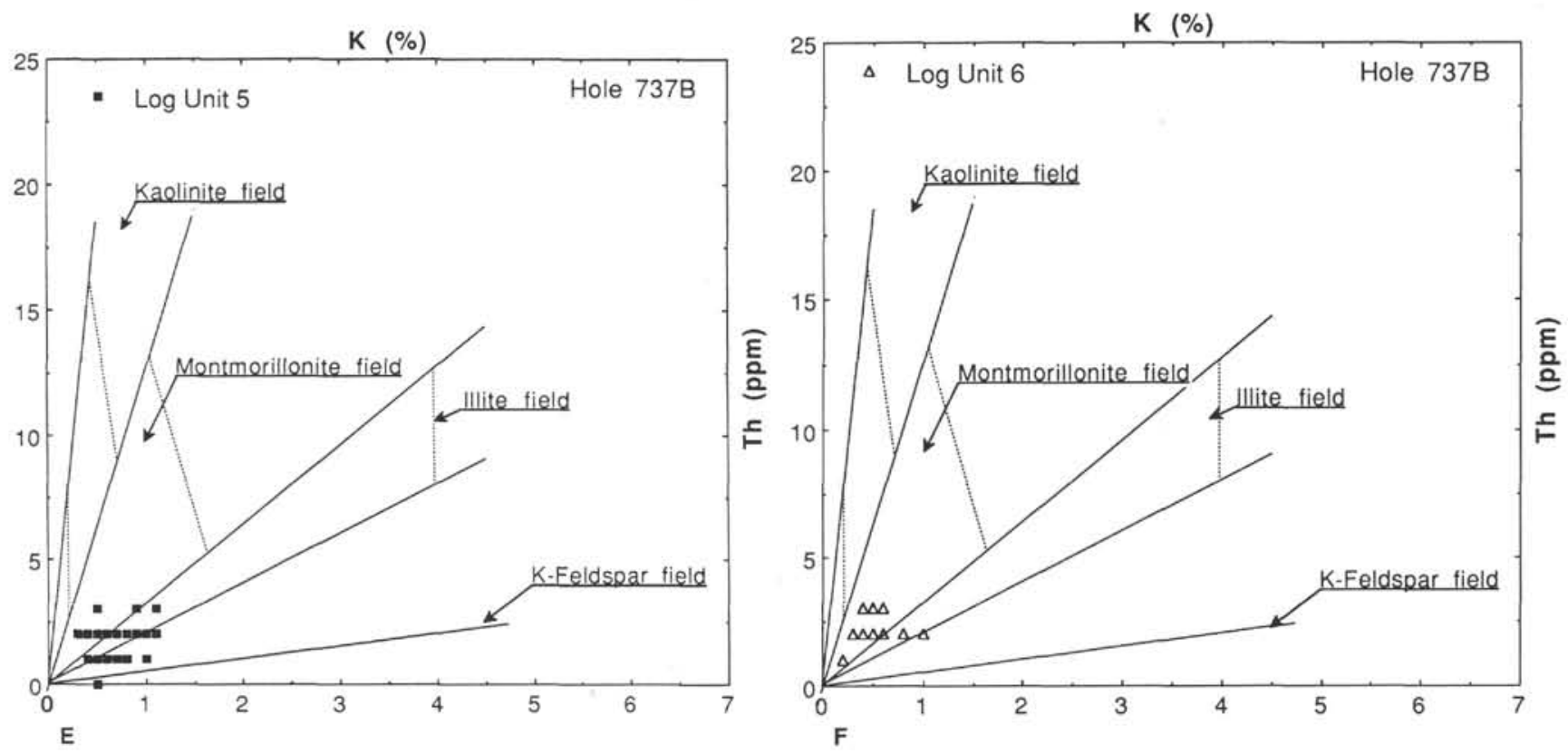

Figure 13 (continued).

probably not recovered by coring. Also, two depth intervals at least (160.0-161.0 mbsf and 200.0-215.0 mbsf) presents well correlated peaks of high velocity, low density, low porosity, and low PEF values, which corresponds to physical characteristics of siliceous matter (Fig. 4). These peaks are interpreted in the present sedimentary environment as chert layers (lithofacies 3), and as the indurated chalk layers, they probably contribute to the bad core recovery within logging Unit 1 .

\section{Logging Unit 2 (250.0-405.0 mbsf)}

Logging Unit 2 corresponds to lithologic Unit 5, which is described as calcareous chalk. The plotted data of logging Unit 2, although scattered, fall close to the limestone line of the RHOBNPHI diagram (Fig. 14A). This plot shows that the material of logging Unit 2 is more compacted than in Unit 1, with porosity ranges from $40 \%$ to $50 \%$ and density from 1.7 to $2.3 \mathrm{~g} / \mathrm{cm}^{3}$. This compaction effect is also seen on the density-porosity crossplot from cores, which exhibits measured density and porosity values significantly lower than in the previous unit (Fig. 15). The resistivity and sonic logs, which are directly related to the porosity, stop rising with increasing depth at the top of the unit (Fig. 4). This signifies that the overburden load is not able to expel water in this unit anymore, probably because of the lithification of the oozes. The few cored intervals recovered within this unit correspond to a chalk lithology, and the previous log characteristics compared with the physical properties measurements on the core enable us to extrapolate this lithology to the entire interval. The PEF values appear significantly lower $(2.5 \mathrm{~b} / \mathrm{e})$ in the lower chalk interval (325.0-380.0 mbsf) than in the upper chalk interval (3.0 b/e) (Fig. 4). The PEF-N crossplot (Fig. 14D) indicates that the decrease of the PEF values in the lowermost part of the chalk induces a shift toward the quartz and opal poles. As multiple peaks of increase in sonic velocity are observed correlating with the low PEF value intervals, it suggests the presence of chert layers or nodules, as those described from the cores. On the lithologic column (Fig. 5), chalk corresponds to lithofacies 4 , whereas siliceous chalk or chert layers are lithofacies 3 .

\section{Logging Unit 3 (424.0-455.0 mbsf)}

The depth interval corresponding to logging Unit 3 is described as limestone from the cores. The continuity of the log records allows us to characterize precisely the boundary between logging Units 2 and 3. Unlike the gradual decrease in porosity values between ooze and chalk in the upper logged intervals, the NPHI log exhibits an abrupt decrease in neutron porosity from $55 \%$ at the base of the chalk unit to $27 \%$ at the top of the limestone unit, attesting to a major change in the nature of the calcareous sequence (Fig. 4). The RHOB-NPHI and RHOB-DT crossplots (Figs. 14A and 14B) show that Unit 3 perfectly fits with a limestone lithology with porosity values ranging from $20 \%$ to $30 \%$. The present depth interval was better recovered than the previous ones, although about $50 \%$ of the material was not recovered by cores. Because the log records do not exhibit major changes within this depth interval, the limestone lithology (lithofacies 8 ) may be extrapolated to the nonrecovered sections (Figs. 4 and 5). The relatively high transit time and porosity values visible on the RHOB-NPHI and RHOB-DT diagrams (Figs. 14A and 14B) and the low $N$ parameter values (Fig. 14E) would suggest a slight increase in clay content, up to $10 \%$ within some limestone layers (lithofacies 7). On a PEF-N crossplot (Fig. 14E), high PEF values - greater than $5.08 \mathrm{~b} / \mathrm{e}-$ occur, thus indicating the presence of dense elements such as iron and manganese. On the lithologic column this facies is termed ferruginous or manganiferous porous limestone of lithofacies 6 (Fig. 5). As with the overlying chalk unit, peaks of decrease in PEF values are interpreted as a minor siliceous facies, which is represented on the lithologic column by lithofacies 5 .

\section{Log-Inferred Lithology in the Glaciomarine Sequences of the Antarctic Shelf (Prydz Bay Area)}

\section{Hole 742A (Fig. 7)}

The lithology proposed from cores within the logged section (30.8-283.8 mbsf) in Hole $742 \mathrm{~A}$ is described as a very uniform diamictite sequence of glaciomarine origin (Hambrey et al., this 

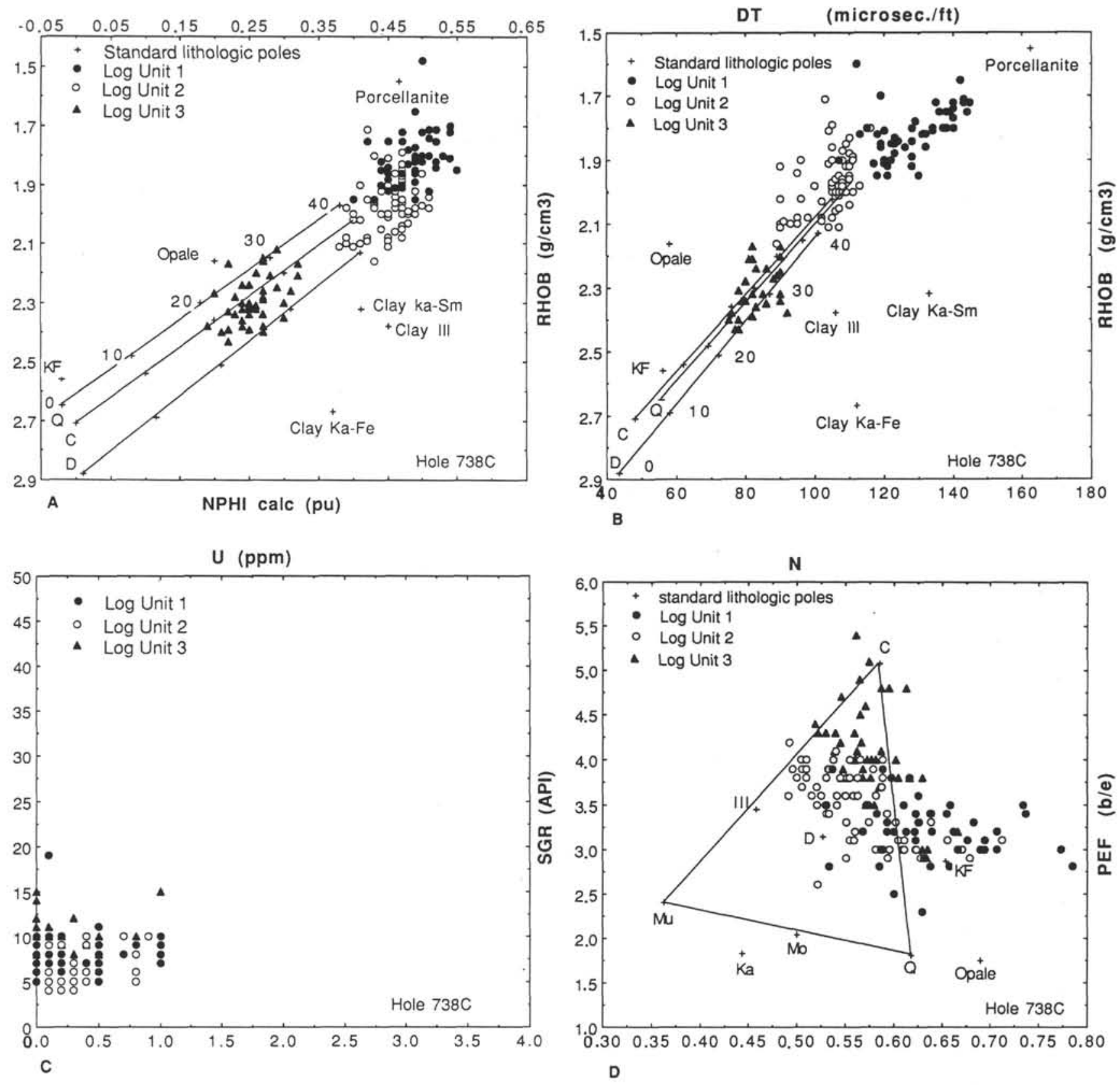

Figure 14. Lithological and mineralogical crossplots in Hole 738C. The crossplots were used by Schlumberger (1988) and Mathis (1988). The mineralogic and lithologic poles and fields are from Augier (1980), Serra (1985), and Ellis et al. (1988). A. RHOB-NPHI crossplot for the entire logged section. B. RHOB-DT crossplot for the entire logged section. C. SGR-U crossplot for the entire logged section. D. PEF-N crossplot for the entire logged section. E. PEF-N crossplot for logging Unit 3.

volume). However, the logs appear to be in contrast with respect to the lithology description, thus suggesting a lithology less uniform than that indicated from the cores (Fig. 6). The diamictites of the Prydz Bay area are described as unsorted sediments from various origins, usually consisting of gneissic or granitic pebbles and blocks floating in a clayey silty-sandy matrix (Hambrey et al., this volume). The logging tools are influenced by the various components of the diamictites to give average responses that integrate the elementary responses of each component. Figure 7 shows the lithologic column which results from the log interpretation, and the comparison between logs and core observations. Also shown are the NPHI and RHOB curves which are not corrected for hole size effect. This is only a matter of representa- tion, because we think that these original curves, as a result of the cave effect, emphasize the contrast between hard and soft layers and between compacted and less compacted units. However, the data plotted in the various lithologic crossplots, and used to define the final lithofacies, were selected within depth intervals where the hole was not enlarged.

The core density-porosity crossplot shows the linear relationship between these two parameters in the diamictite, within the $15 \%-45 \%$ porosity interval (Fig. 16). The plotted data, of the diamictites, mostly fall on the dolomite line of the RHOBNPHI crossplot (Fig. 17A), whereas they fall on and in the vicinity of the kaolinite-smectite clay pole in the RHOB-DT crossplot (Fig. 17B). These data plot close to the montmorillonite 
N

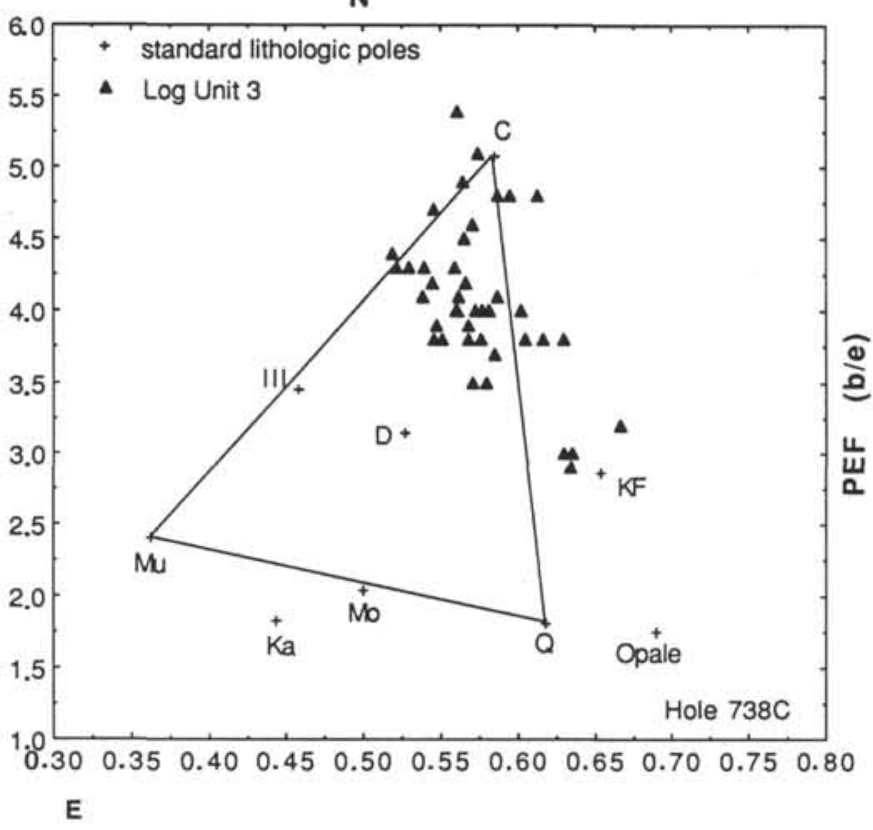

Figure 14 (continued).

Porosity in $\mathrm{Pu}$

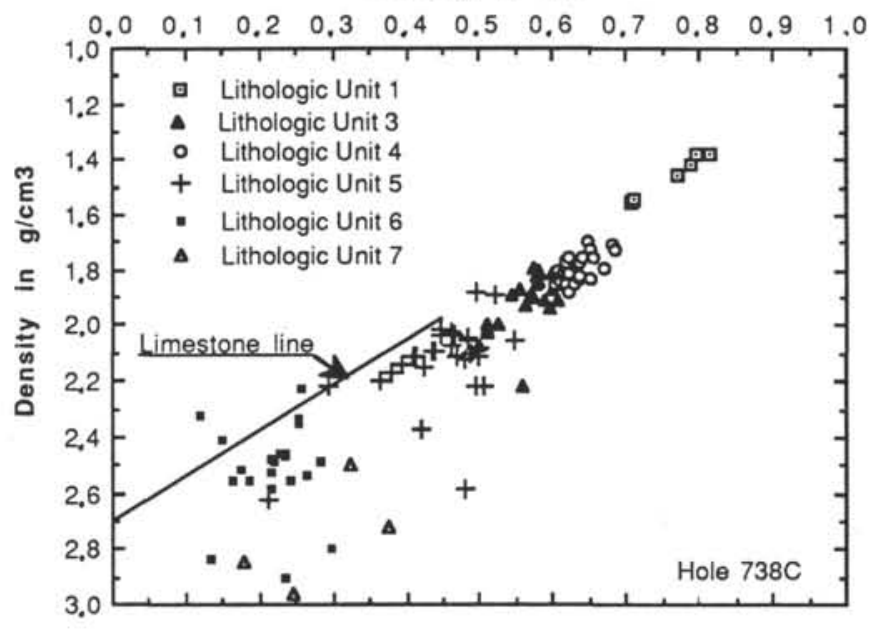

Figure 15. Density-porosity crossplot from core measurements in Hole 738C. The densities, porosities and the lithologic units are from Barron, Larsen, et al. (1989).

pole and field of the PEF-Th/K diagram and the Th-K diagrams, respectively (Figs. 17C and 17D). The large amount of radioactive elements, coming from the erosion of the metamorphic basement, gives a high general radioactivity to the glacial sediments, which is always greater than 80 GAPI units on the SGR $\log$ and usually ranging between 110 and 140 GAPI units (Figs. 17E and 6); it is thus impossible to infer the clay content of these formations from the SGR log. However, the comparison between the log records, and particularly the porosity logs, with the granulometry curves from Hambrey et al. (this volume), will in some cases give qualitative information about the clay content of the diamictites. The diamictites have a constant PEF value of $2.5 \mathrm{~b} / \mathrm{e}$, except in the lower logged section where the lithodensity tool responses were severely influenced by cav-

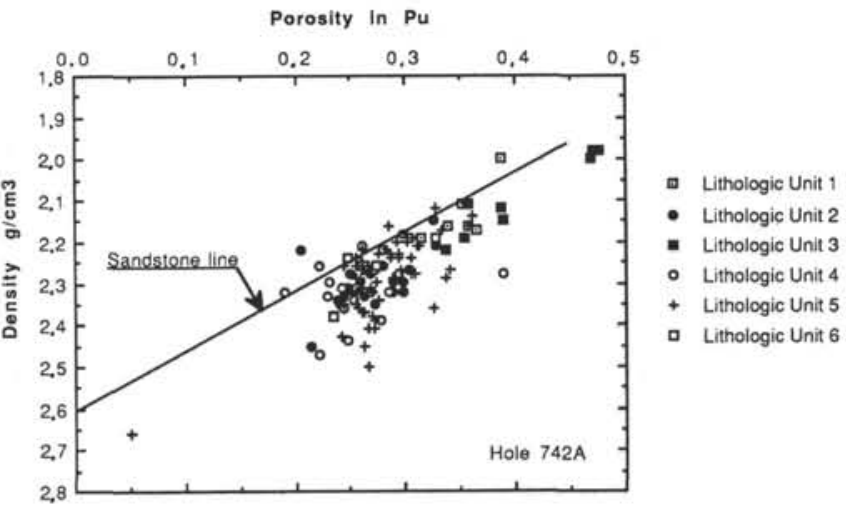

Figure 16. Density-porosity crossplot from core measurements in Hole $742 \mathrm{~A}$. The densities, porosities, and the lithologic units are from Barron, Larsen, et al. (1989).

ing (Fig. 6). Granito-gneissic-rich debris layers are characterized by high thorium and potassium contents that commonly exceed the theoretical content of the clay fields (Fig. 17D). These layers also show strong PEF values that are likely related to a significant iron content (Fig. 17F).

At Hole 742A, logs allow the identification of eight lithofacies spread over four logging units (Fig. 7). The RHOB-NPHI and RHOB-DT crossplots for the entire logged section (Figs. 17A and 17B) and the shape of the logging curves (Fig. 6) allow differentiation of two main kinds of diamictites at Hole 742A (Fig. 7). The first type matches massive highly compacted diamictites (lithofacies 5) with porosities ranging from $25 \%$ to $35 \%$ (logging Unit 1, 33.8-117.7 mbsf, and logging Unit 3, 140.8$172.8 \mathrm{mbsf}$ ). The second type of diamictites matches stratified diamictites (lithofacies 4) with porosities greater than $35 \%$ (logging Unit 2, 117.7-140.8 mbsf, and logging Unit 4, 172.8-253.8 mbsf). On the RHOB-NPHI and RHOB-DT diagrams the plotted data corresponding to logging Units 1 and 3 are grouped, whereas the plotted data corresponding to logging Units 2 and 4 are scattered, thus emphasizing the difference between the relatively homogeneous composition of the compacted diamictites and the variable composition of the stratified diamictites (Figs. $17 \mathrm{~A}$ and $17 \mathrm{~B})$.

\section{Logging Unit 1}

Logging Unit 1 matches lithologic Unit 2, which is described as homogeneous and massive diamictite by Hambrey et al. (this volume). The logging parameters within this poorly recovered depth interval remain fairly constant, which indicates no major lithologic change (Fig. 6). So, we proposed to extrapolate the massive diamictite lithology to the entire unit (lithofacies 4). Within the massive diamictite a secondary facies characterized by high thorium and potassium contents can be distinguished (Fig. 17D). This secondary facies (lithofacies 6) is thought to consist of diamictites containing numerous pebbles and blocks of metamorphic and granitic origin, as confirmed by the number of clasts found in the few recovered cores.

\section{Logging Unit 2}

According to the logs, the stratified diamictite sequence of Unit 2 is more heterogeneous than that of Unit 1 (Fig. 6). It is in good agreement with the observations of the cores (Hambrey et al., this volume). With respect to logging Unit 1 , a significant increase in porosity, from at least $10 \%$ according to the NPHI $\log$, occurs within logging Unit 2 . We can note that this increase in porosity value influences all the log records (sonic log, density $\log$, resistivity $\log$, and neutron porosity log). By comparing 

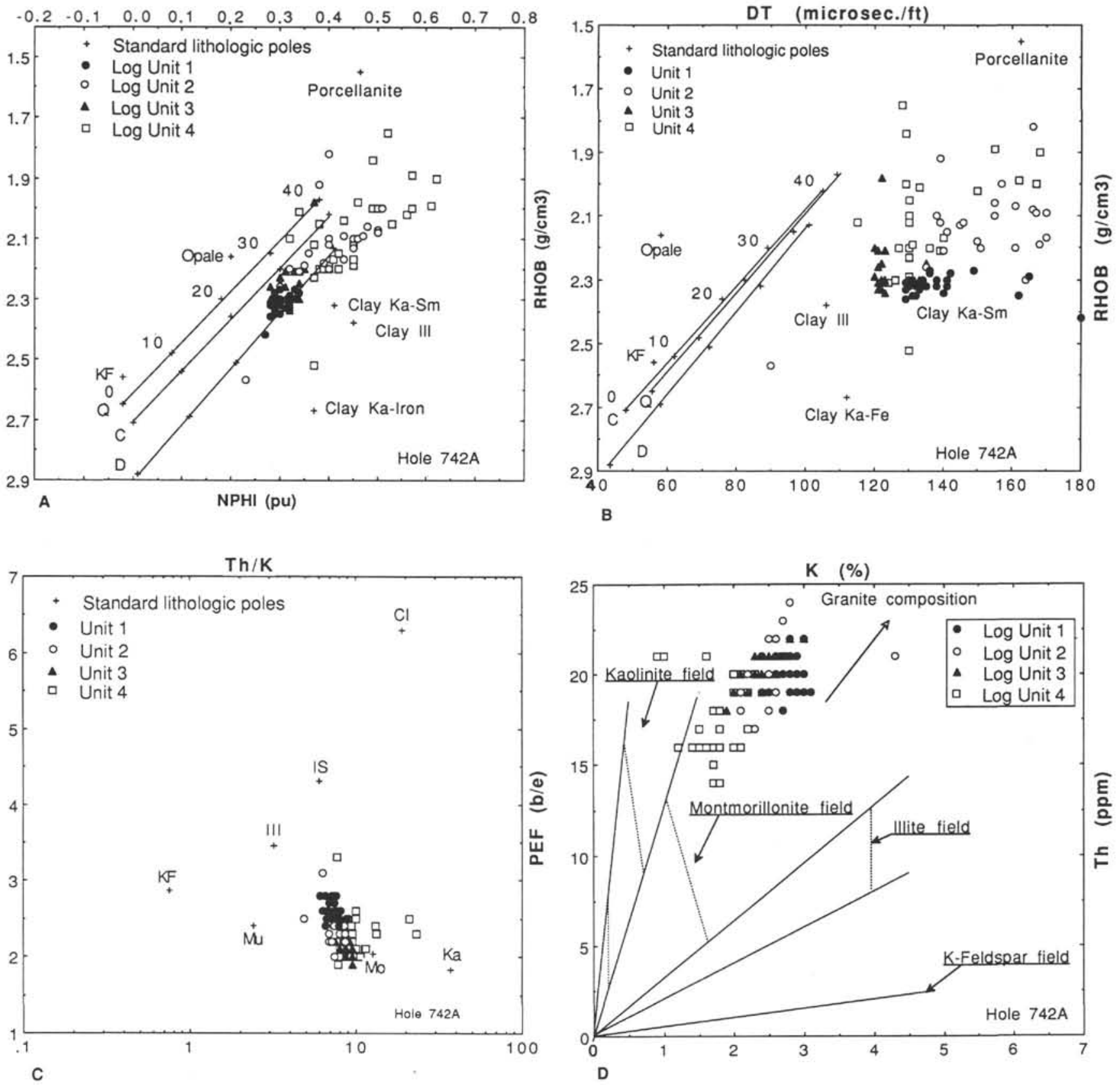

Figure 17. Lithological and mineralogical crossplots in Hole 742A. The crossplots were used by Schlumberger (1988) and Mathis (1988). The mineralogic and lithologic poles and fields are from Augier (1980), Serra (1985), and Ellis et al. (1988). A. RHOB-NPHI crossplot for the entire logged section. B. RHOB-DT crossplot for the entire logged section. C. PEF-Th/K crossplot for the entire logged section. D. Th-K crossplot for the entire logged section. E. SGR-U crossplot for the entire logged section. F. PEF-N crossplot for the entire logged section.

the log curves with the sand/mud-ratio curve provided by Hambrey et al. (this volume), one notices that the increase in porosity is closely related to a decrease in the mean grain size of the diamictites, which appear mainly as muddy diamictites within this interval. The increase in porosity related to fine muddy material suggests a clay-rich-diamictite unit (lithofacies 5). The presence of a clay-rich-diamictite facilitates the washout of the hole during drilling, which explains the numerous caves identified within this interval. The unit contains some layers rich in thorium and potassium, thus indicating the presence of higher amounts of granitic components (Fig. 18A). The recovery of one $62-\mathrm{cm}$ boulder of gneiss and several individual cobbles within logging Unit 2 (Hambrey et al., this volume), suggests that in the nonrecovered interval the rich thorium and potassium electrobanks may be interpreted as boulders. Locally, indurated diamictite layers, having the same characteristics than those from Unit 1 and $N$ parameters ranging from 0.5 to 0.6 , are also interbedded in this unit (Fig. 18B). Minor lithologic facies are also identified within Unit 2. Ferruginous diamictites corresponding to lithofacies 8 are identified on the PEF-N crossplot in the region of high PEF values (Fig. 18C). Plotted data falling close to the opal pole on the N-P, PEF-N, and RHOBDT crossplot (Figs. 18B, 18C, and 17B) suggest the presence of few diatomite layers (lithofacies 1) within Unit 2. 


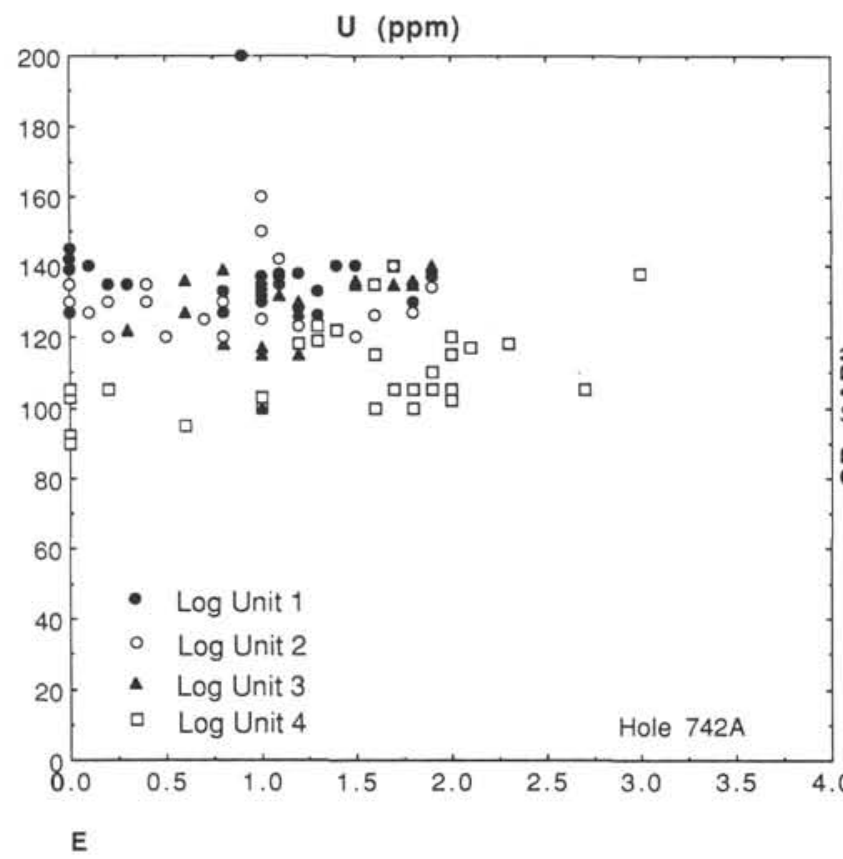

Figure 17 (continued).

\section{Logging Unit 3}

Logging Unit 3 corresponds to lithologic Unit 4 (Hambrey et al., this volume), and is described as a massive diamictite. According to logs, the compacted diamictite Unit 3 shows very little lithologic variations; it consists mainly of lithofacies 4 (Fig. 7). One can distinguish only one secondary lithofacies (lithofacies 6), previously identified as diamictites rich in basement pebbles (Fig. 18D).

\section{Logging Unit 4}

On the logs, the stratified diamictite of Unit 4 looks very much like those of Unit 2 (Fig. 6). In particular, the top of the unit (175.0-205.0 mbsf) exhibits a significant increase in porosity, well correlated with a decrease of the sand/mud-ratio (Hambrey et al., this volume), which suggests a clay-rich diamictite interval (lithofacies 5). In the lowermost part of logging Unit 4, from 205.0 to $233.3 \mathrm{mbsf}$, the diamictites have mostly the same $\log$ characteristics as those described for lithofacies 3. Besides these compacted diamictites representing the major lithologic facies, some slight differences appear in the secondary and minor lithologies. Sand or sandy diamictite layers occur here as a significant lithology and form an important secondary lithofacies (lithofacies 2 ). These sandy layers are characterized by high sonic transit time values, low density values, and high porosity values resulting in abnormally low values of $N$ parameters (Figs. 17B and 17F). A good example of this kind of lithology is a 15m-thick layer between 215.0 and 230.0 mbsf on the lithologic column that was not recovered by coring (Fig. 7). In addition to the minor lithologies recognized within Unit 2, some slightly calcareous diamictites appear here, characterized by higher PEF values correlated to weaker sonic transit times (lithofacies 7) (Figs. 17B and 17F). No diatomite layers such as those found in Unit 2 were identified within this unit.

\section{Hole 739 C (Fig. 9)}

As for Hole $742 \mathrm{~A}$, the density-porosity crossplot from core data at Hole $739 \mathrm{C}$ indicates a clear linear relationship between these two parameters (Fig. 19). Four logging units were distinguished in Hole 739C. On these four units, five lithofacies were

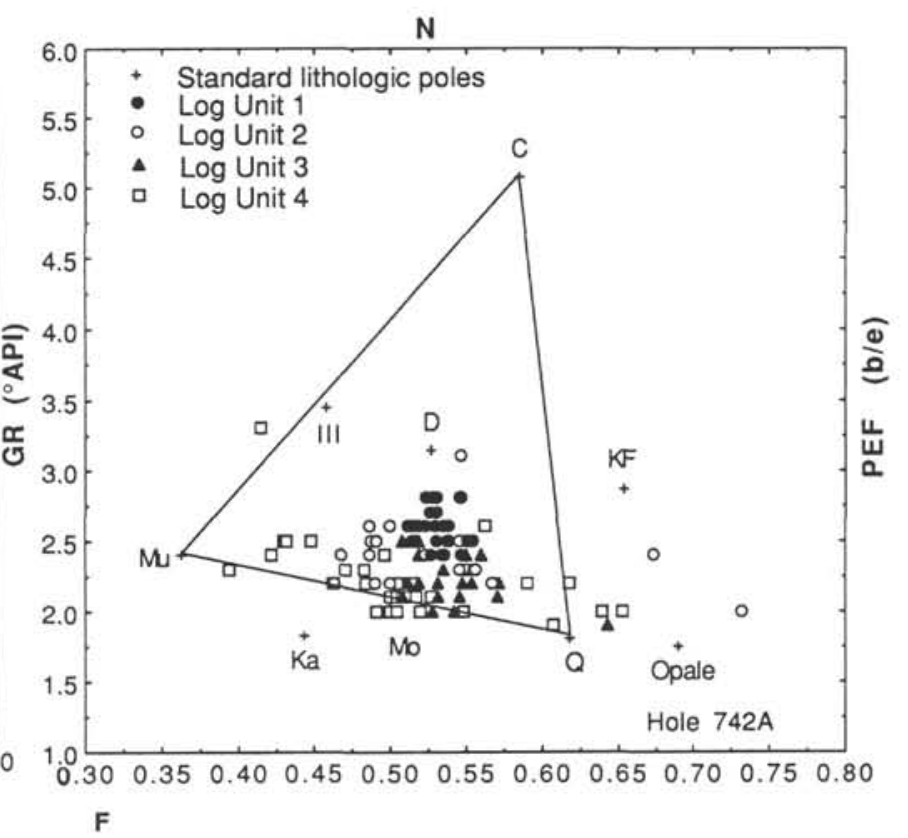

defined on the basis of comparisons between the mineralogic and the lithologic crossplots and the core descriptions (Fig. 9). The lithologic column shown on Figure 9 is represented between the GR log and the PHI SON log. In order to provide some lithologic information within the nonrecovered intervals, and as no density logs are available at this site, the core densities have been used in the lithologic crossplots combined with the log data. On the core density-PHI SON and core density-DT crossplots (Figs. 20A and 20B), the plotted data of the diamictites fall in the same regions than those of the RHOB-NPHI and RHOB-DT crossplots at Hole 742A (Figs. 17A and 17B). As in Hole $742 \mathrm{~A}$, the grouped data in the density-NPHI SON crossplot and in the density-DT crossplot correspond to massive, highly compacted diamictites (logging Units 2 and 4), whereas the scattered ones correspond to less compacted stratified diamictites (logging Units 1 and 3).

\section{Logging Unit 1 (32.0-110.0 mbsf)}

The dominant facies of this logging unit is characterized by relatively high calculated porosity values (PHI SON), ranging around $40 \%$ (Fig. 10). Within this depth interval, the core porosity does not fit at all with the calculated porosity from the sonic log which is systematically about $10 \%$ higher. This may be due to the small number of available core data, which probably are not representative to the porosity of the entire interval. In order to obtain the lithologic crossplots (Figs. 20A and 20B), the few core density measurements available for the present depth interval were extrapolated to the entire interval. The data were plotted on this diagram in the same area as for Units 2 and 4 of Hole $742 \mathrm{~A}$. For this very poorly recovered section we propose the general term of less-compacted stratified diamictites (lithofacies 1) in accordance with Hole 742A. The term stratified is suggested within the lower part of the unit by the alternations visible on the log curves (Fig. 8). Within the alternating zone, the peaks of high radioactivity suggest the presence of metamorphic and granitic blocks and pebbles (lithofacies 2).

\section{Logging Unit 2 (110.0-175.0 mbsf)}

According to the core description, logging Unit 2 (110.0$175.0 \mathrm{mbsf}$ ), which was almost completely recovered, consists 
K (\%)

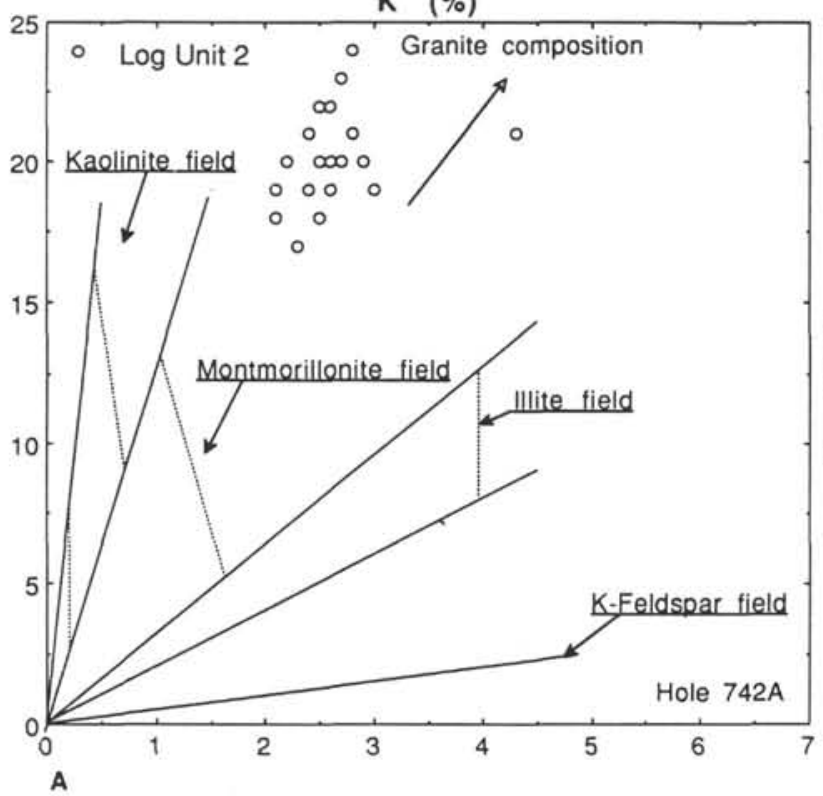

$\mathrm{N}$

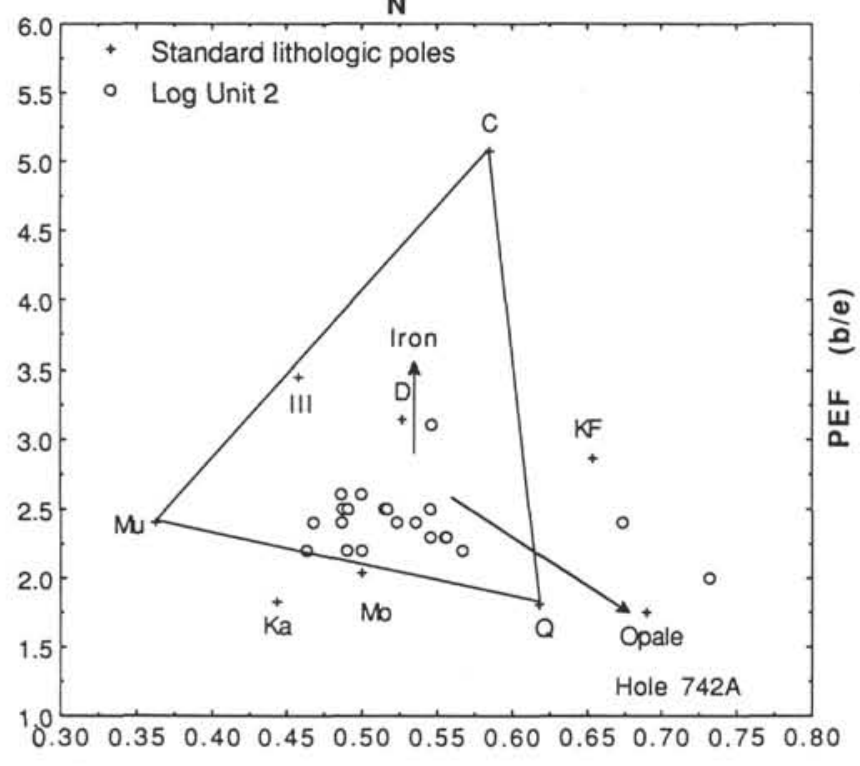

c

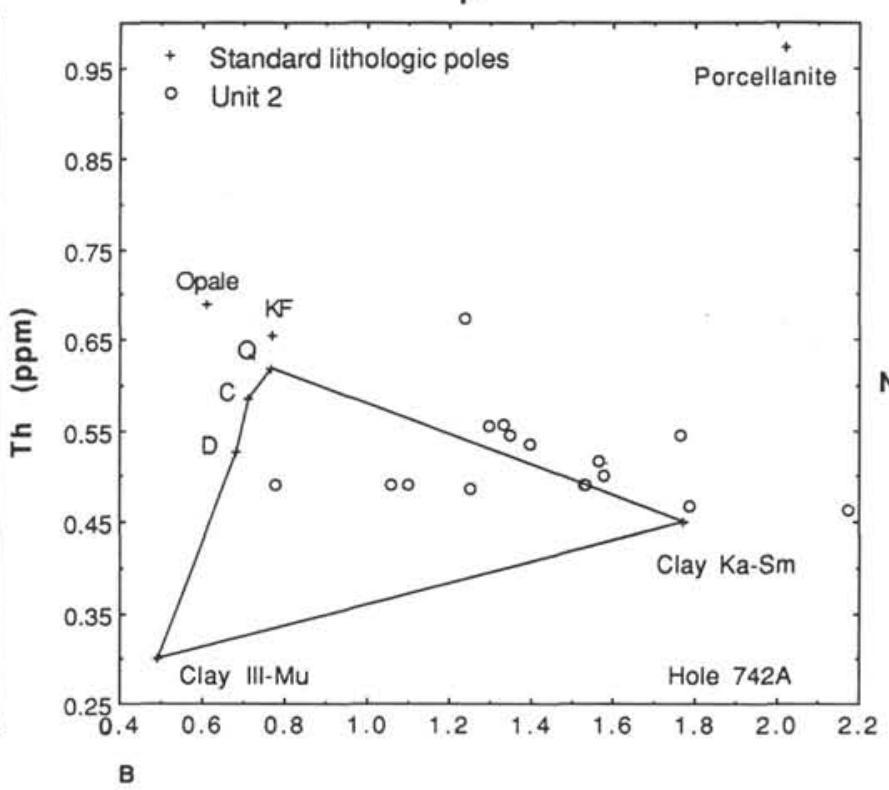

K (\%)

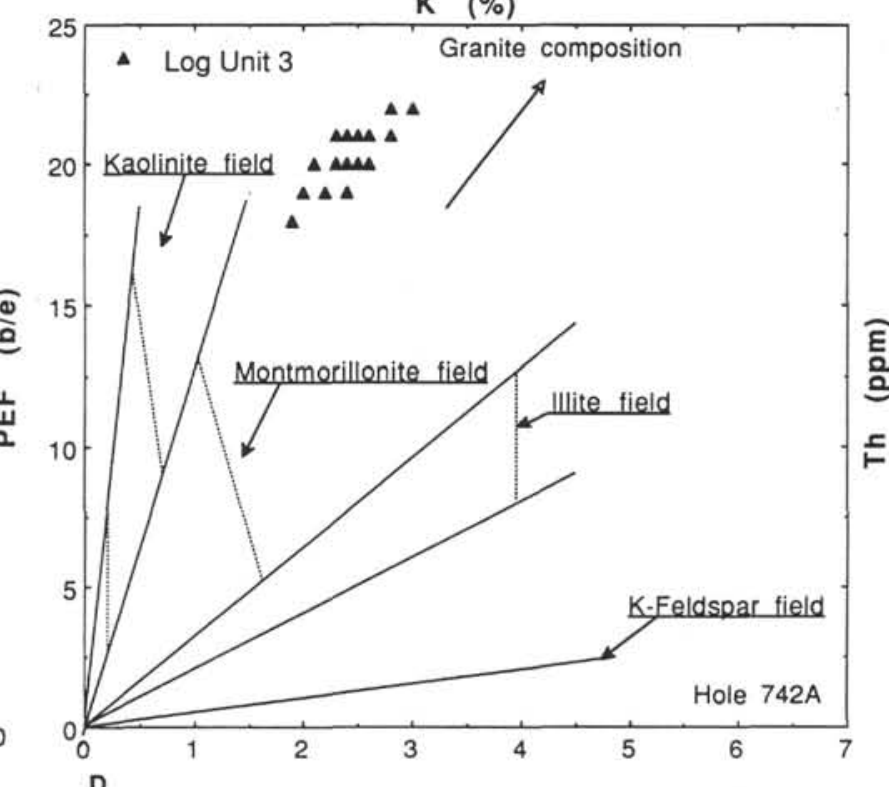

Figure 18. Lithological and mineralogical crossplots in Hole 742A. The crossplots were used by Schlumberger (1988) and Mathis (1988). The mineralogic and lithologic poles and fields are from Augier (1980), Serra (1985), and Ellis et al. (1988). A. Th-K crossplot for logging Unit 2. B. N-P crossplot for logging Unit 2. C. PEF-N crossplot for logging Unit 2. D. Th-K crossplot for logging Unit 3.

mainly of massive diamictites. On the logs, and by comparison with the previous logging unit, the material of logging Unit 2 looks considerably more homogeneous (Fig. 20C). The porosity values drop abruptly, suggesting highly compacted diamictites (lithofacies 3) in this unit (Figs. 8 and 10). A minor lithology identified at $141.1 \mathrm{mbsf}$ is characterized by high transit time, low resistivity, high porosity values, and an abrupt drop in radioactivity (Figs. 8 and $20 \mathrm{C}$ ). The log characteristics of this layer suggest a lithology (lithofacies 5) significantly different than the surrounding one, probably consisting of more sandy material. The core density-PHI SON and N-P plots for logging Unit 2 are similar to the ones established for logging Units 1 and 3 of Hole 742A (Figs. 20C and 20D).

\section{Logging Unit 3 (175.0-315.0)}

In logging Unit 3, the logging curves exhibit shapes corresponding to peaks and gradients related to contrasting lithologies (Figs. 8 and 10). The general porosity level increases significantly within this unit, except between 200.0 and 225.0 mbsf (Fig. 4). The increases in porosity within the unit are well correlated with the decreases of the sand/mud-ratio observed by Hambrey et al. (this volume). As for Hole $742 \mathrm{~A}$, it suggests a clayrich diamictite interval (lithofacies 4 ). Also, the general radioactivity level decreases significantly within the unit, probably indicating a major change in the source material of the diamictites (Fig. 8). On the core density-PHI SON plot, the data of Unit 


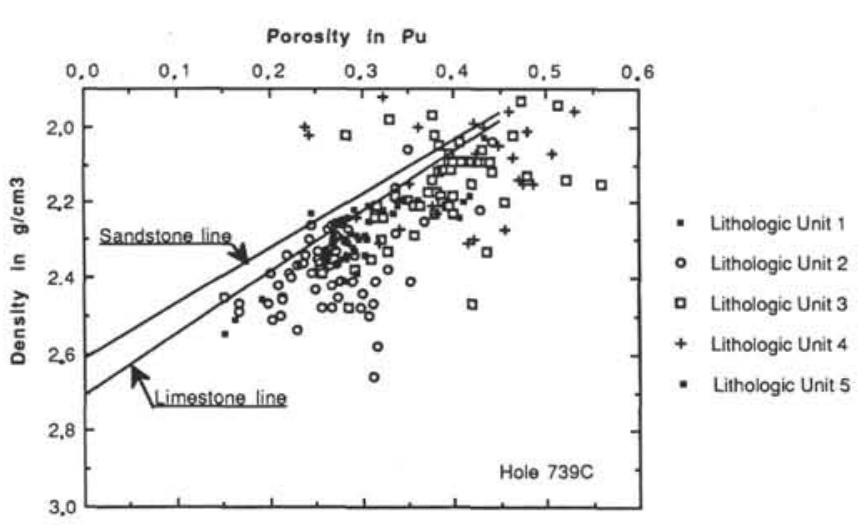

Figure 19. Density-porosity crossplot from core measurements in Hole 739C. The densities, porosities, and lithologic units are from Barron, Larsen, et al. (1989).

3 fall in the same area as those in the Unit 1 (Figs. 20A and 20B), which suggests a general lithology similar to the stratified, less-compacted diamictites of Unit 1. However, a compacted diamictite bank (200.0-225.0 mbsf) is interbedded within uncompacted diamictite in Unit 3 (Fig. 8). The lithologic changes in Unit 3 are due in part to the presence of low-radioactivity layers and low-porosity layers, which are thought to correspond to sandy diamictites or sand layers (lithofacies 5) (Fig. 8).

\section{Logging Unit 4 (315.0-468.0)}

Within logging Unit 4, the core density-PHI SON plot (Fig. $20 \mathrm{E})$ allows identification of two lithofacies: one major lithofacies with low porosity ranging from $25 \%$ to $35 \%$, and a second minor facies with porosities greater than $35 \%$. By comparison with the few cored intervals, this major lithologic facies would correspond to massive unstratified, poorly sorted diamictites (lithofacies 3). A minor facies, with high porosities was not sampled (Figs. 8 and 9) and is thought to correspond to sandy diamictites or sand layers. Strings of high radioactivity at the base of the unit are interpreted as boulder- or pebble-rich-basement pebble layers.

\section{DISCUSSION}

\section{Hole 737B}

Within logging Unit 1 the shape of the logging curves confirms the turbiditic origin of the silt layers as suggested by the cores: the sharp contact at the base of the electrobanks is characteristic of strong and exceptional sedimentary events (Serra, 1985) (Fig. 2).

Only the relatively uniform lithologic Unit 5, described as a calcareous claystone unit, was identified from the cores between 321.1 and $677.9 \mathrm{mbsf}$, whereas four units were distinguished from logs within this depth interval (logging Units 2, 3, 4 and 5; Fig. 3). These four logging units mainly represent gradual steps in the decrease of the porosity values with increasing depth, which corresponds to the diagenetic transformation of the calcareous oozes into limestones. This process is usually progressive; however, it may also appear abruptly, as within Unit 3 ( $377.5 \mathrm{mbsf}$ ), where a jump on the $\log$ record is due to an abrupt decrease in the porosity value (Fig. 2). The diagenetic front identified within logging Unit 3 corresponds to the time boundary between the early Oligocene and the late Oligocene and may represent a short hiatus (Barron et al., chapter 46 , this volume). The differences in the clay content and nature of the studied logging units also reveal information about the detrital influences within the calcareous biogenic deposits. The maxi- mum arrival of detritus seems to have occurred mainly during the middle Miocene (logging Unit 1), and during the end of the early Oligocene and the beginning of the late Oligocene (logging Unit 3). The minimum of detrital influence seems to have occurred in the middle Eocene (logging Unit 6).

\section{Hole 738C}

The detrital influence in Hole $738 \mathrm{C}$ within the logged section appears to be minimum, unlike in the previous hole. The log-inferred clay content is near $0 \%$. The lithology inferred from logs is divided into three logging units which fit perfectly with the description from cores. However, the logs in this hole supplement the core description because the recovery was rather incomplete during the drilling operations $(57.6 \%)$ (Barron, Larsen, et al., 1989). This is particularly the case in the lower part of the calcareous ooze unit and in the upper part of the chalk unit. The logs do not enable us, in this hole, to resolve with accuracy the siliceous lithology; however, some chert layers or siliceous chalk intervals are identified on the lithologic plots, but the in-situ geochemical information is tremendously lacking for a better interpretation. The vertical resolutions of the tools are also probably too low to resolve centimeter-scale chert layers and nodules.

\section{Hole 742A}

The four logging units defined from logs in Hole $742 \mathrm{~A}$ correspond to the four lithologic units described from the cores (lithologic Units 2, 3, 4 and 5). The log interpretation emphasizes the lithologic differences between highly compacted diamictites (logging Units 1 and 3) and less compacted diamictites (logging Units 2 and 4). The comparison between the porosity log and the sand/mud ratio from Hambrey et al. (this volume) confirms the correlative increase in clay content of the diamictites with increasing porosity (Solheim et al., chapter 8 , this volume). The clay-rich diamictites mostly correspond to the stratified intervals, whereas the diamictites with less clay match the massive intervals. The "pipe" shape of the log-inferred lithologic column within the highly compacted diamictites indicates a massive deposit, consisting of pebbly mudstone with the same characteristics from the base to the top of the unit (Fig. 7). The logs within the less compacted diamictites exhibit alternations corresponding to a varied lithology (pebble layers, diatomites, and indurated diamictites) and to porosity gradients (from non-indurated to indurated lithologies). So, although the sedimentary source is identical for both kinds of units (Antarctic, metamorphic, and granitic basement sediments), as revealed by the uniformity of the PEF log, the differences in the organization and in the texture of the two kinds of units suggest two kinds of sedimentary processes. The massive diamictites correspond to what Edward (1978) calls unstratified till, which is usually thought to have been deposited in the proximal area of the glacial system at the base of a grounded glacier. The less compacted ones, termed stratified tillites by Edward (1978), are typically of a glaciomarine origin and were deposited seaward of the previous deposits (Fig. 21). The physical characteristics of the stratified diamictites have already been reported by Easterbrook (1964), who described these as lower-density and higher-porosity sediments than the proximal glacial sediments, which is in good agreement with the present log data. From seismic interpretations (Cooper et al., this volume), lithologic Units I, II, and III correspond to flat shelf reflectors, whereas Unit IV corresponds to steep slope reflectors. The presence of sands in logging Unit 4 would confirm these slope facies. However, it is interesting to note that the seismic data only enable us to identify one unit PS1, whereas cores and logs allow the recognition of three distinct units (logging Units 2, 3, and 4). The physical characteristics of the sediments, such as density and sonic transit time, change tremendously at 


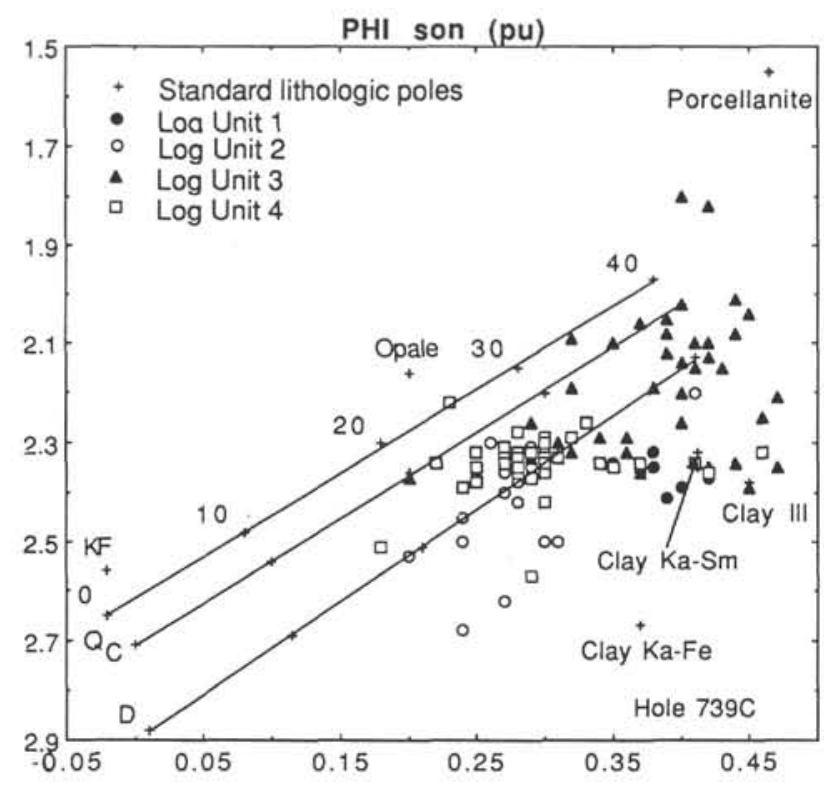

A

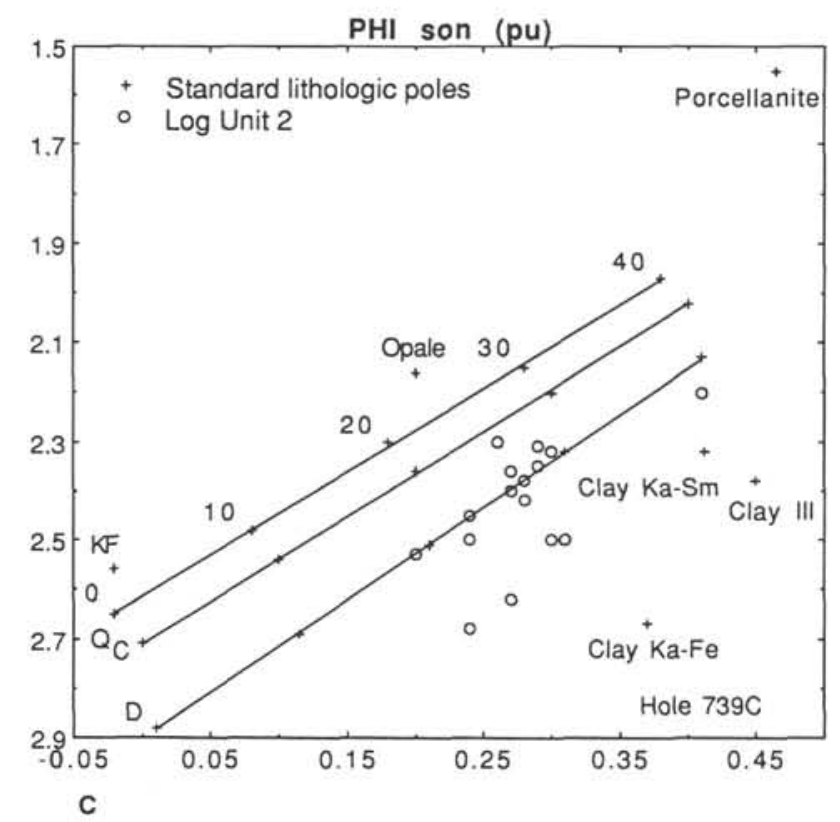

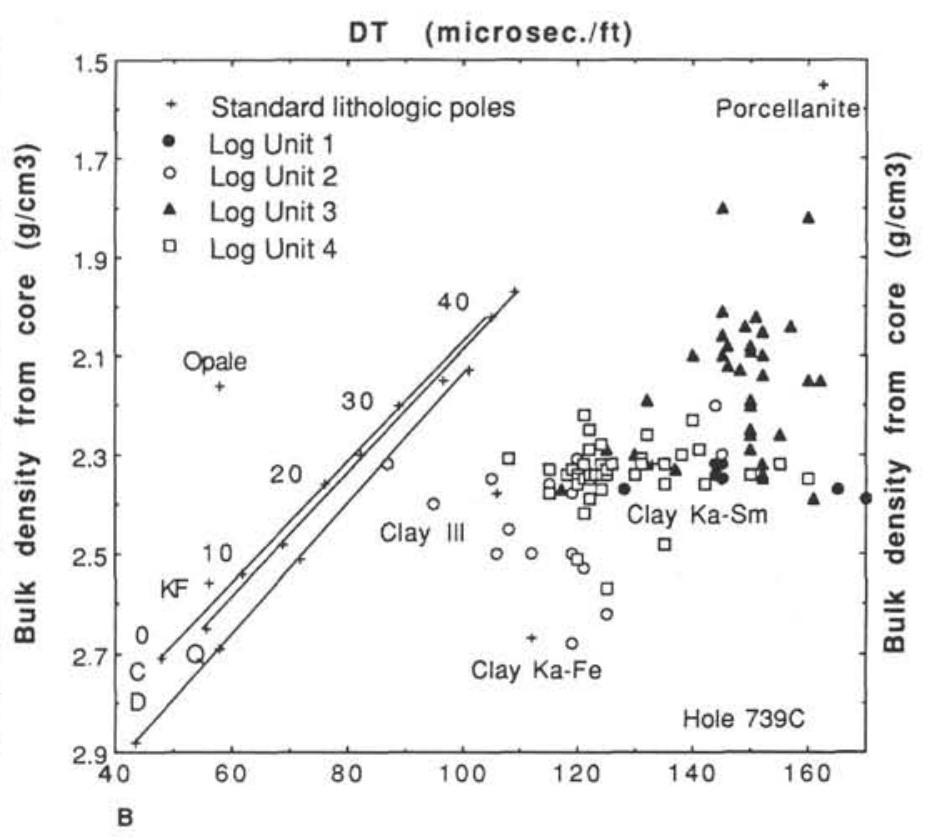

$\mathbf{P}$

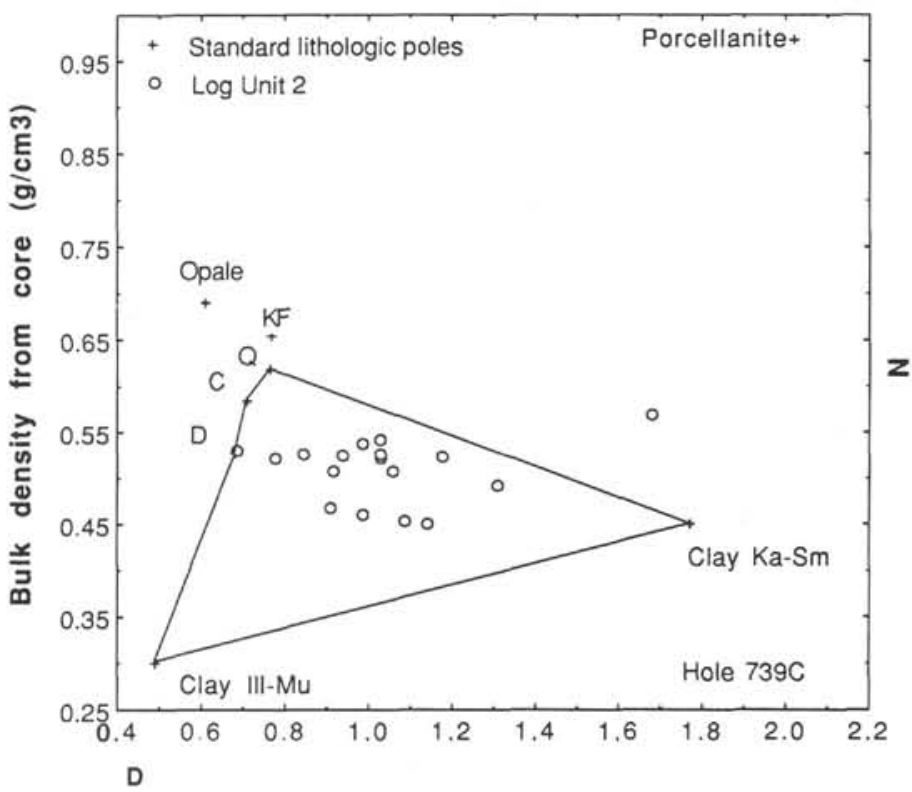

Figure 20. Lithological and mineralogical crossplots in Hole 739C. The crossplots were used by Schlumberger (1988) and Mathis (1988). The mineralogic and lithologic poles and fields are from Augier (1980), Serra (1985), and Ellis et al. (1988). The densities measured on core are from Barron, Larsen, et al. (1989). A. Density measured on core and porosity calculated from sonic transit time log (PHI SON) crossplot for the entire logged section. B. Density measured on core and DT cross-plot for the entire logged section. C. Density measured on core and PHI SON crossplot for logging Unit 2. D. N-P crossplot for logging Unit 2. E. Density measured on core and PHI SON crossplot for logging Unit 4.

the top and the base of logging Unit 2 (Fig. 6), causing the expectation of strong seismic reflectors at the boundaries of this unit. One possible explanation is that logging Unit 2 is not very thick (only $30 \mathrm{~m}$ ), which is beyond seismic resolution. The lithologic column inferred from the logs would suggest at least one episode of grounding activity, followed by the deposition of stratified till related to marine conditions during the Pliocene ages. From the late Pliocene to Quaternary the region seems to have been glaciated again as shown by the presence of the massive diamictite of Unit 1.

\section{Hole 739C}

Although only few logs were acquired in Hole 739C, they allowed us to propose a relatively realistic lithologic interpretation by comparison with the recovered core intervals and the lithologic column in Hole 742A. As in Hole 742A, the lithologic column consists mainly of a sequence of massive diamictites deposited at the base of the glacier and less compacted diamictites deposited in seawater. Also, as in the preceding hole, the clayrich diamictites appear to be located in the less-compacted, 


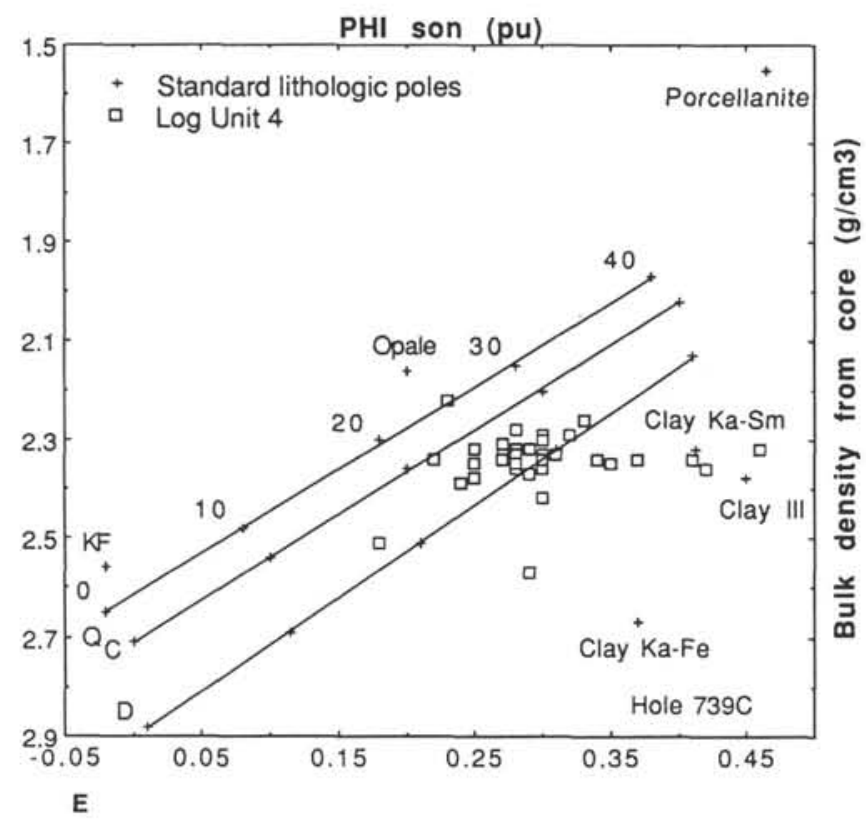

Figure 20 (continued).

stratified intervals. Due to the lack of core recovery within the top of the drilled section, the core description failed to identify the lithology in logging Unit 1 . This unit corresponds to moderately compacted and stratified diamictites (Fig. 9) and was not recognized by the seismic interpretation (Cooper et al., this volume). In Hole 739C, as in Hole 742A, flat shelf glacial deposits (units 1 and 2) overlie slope deposits (units 3 and 4) (Cooper et al., this volume). Taking into account the relatively short distance between the two holes $(30 \mathrm{~km})$, fairly good correlations may be proposed between the upper horizontal units between the logging units. Upper Miocene to Pliocene Units 2 and 1 in Hole 739 C would correspond respectively to Pliocene Units 3 and 2 in Hole 742A. Upper Pliocene to Quaternary logging Unit 1 in Hole 742A does not appear to exist in Hole 739C. These correlations suggest that grounding ice reached at least the location of Hole $739 \mathrm{C}$ in the late Miocene-early Pliocene, whereas in the late Pliocene the grounding line did not even reach Hole $742 \mathrm{~A}$ or deposits were subsequently eroded away. Between the late Pliocene and the Quaternary the grounding line reached the location of Hole 742A.

\section{CONCLUSIONS}

In both the glacigenic and biogenic areas studied, the interpretation of geophysical log data compared to the core data allowed us to infer comprehensive lithologic columns. Although sometimes the log interpretations are still questionable because of the lack of certain kinds of logs, or because of the poor quality of some of these logs, these interpretations improve significantly the knowledge of the sedimentary sequence in the nonrecovered intervals. From a methodologic point of view, the comparison between the bulk density-porosity crossplots from logs and cores allowed us to establish the relationships between these two parameters in the particular lithologies encountered and for the poorly known high porosity intervals.

The results of this study confirm and supplement the description from the cores. In the Kerguelen Plateau holes, the lithologic interpretations from the cores already provided an almost complete lithologic column, but the logging interpretation brings further quantitative information about the shaliness and the porosity of the formations. In Hole 737B, six calcareous logging units, from the middle Eocene to middle Miocene, were differentiated on the basis of their shaliness and porosity. The logs show that the illite content, which is related to detrital influence (Chamley, 1989), is maximum in the lower to upper Oligocene, whereas it is minimum in the middle Eocene. In Hole $738 \mathrm{C}$, three lithologic units of the Campanian-late Eocene, consisting of calcareous oozes, chalk, and limestones, were recognized from both logs and cores. Despite the very bad recovery in

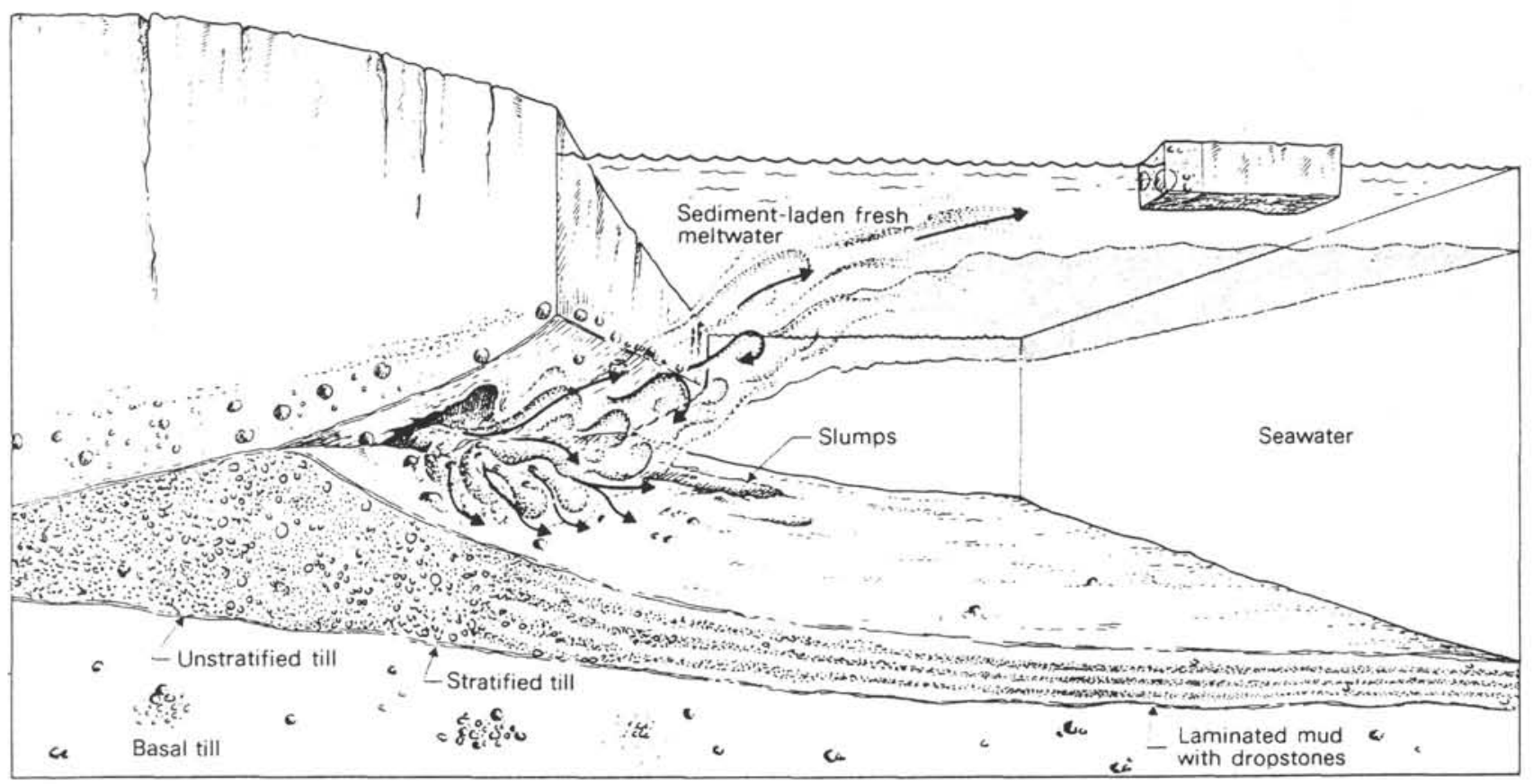

Figure 21. Depositional environment of grounded and marine tillites (after Edward, 1978). 
the Maestrichtian to lower Eocene interval, it was possible on the basis of logs in this hole to follow precisely the transformation of oozes into chalk. In both Kerguelen Plateau holes diagenetic fronts were identified from in-situ physical measurements. These two fronts are located within the very clayey calcareous ooze at the boundary between the upper and the lower Oligocene in Hole 737B, and at the boundary between lower Eocene ooze and chalk in Hole 738C. In the Antarctic Shelf holes, the logs allow us to distinguish compacted massive diamictite units from less-compacted, stratified diamictite units. The compacted diamictites are seen as lodgement tills, whereas the less compacted ones were deposited in seawater (Hambrey et al., this volume). The comparison of the logging units with the seismic data (Cooper et al., this volume) shows that the logging Units 1, 2 , and 3 in Hole 742A and logging Units 1 and 2 in Hole 739C correspond to flat reflectors (PS1), whereas logging Unit 4 in Hole $742 \mathrm{~A}$ and logging Units 3 and 4 in Hole $739 \mathrm{C}$ correspond to slope reflectors (PS2). According to the logs, the depth intervals corresponding to the inclined reflectors have a general lithology different from the horizontal ones; sand layers occur, interbedded with clay-rich diamictites, suggesting distal deposits, which is in good agreement with a slope environment. The correlations between the two holes, based on the logs, indicate that at least one grounding glacier reached the location of Hole 739C in the late Miocene-early Miocene. In the late Pliocene, ice recession seemed to have occurred landward beyond the location of Hole 742A. Between the late Pliocene and the Quaternary age, the grounding line again reached Hole $742 \mathrm{~A}$.

\section{ACKNOWLEDGMENTS}

We wish to thank our colleagues aboard the drillship JOIDES Resolution for helpful discussions and contributions, particularly B. Larsen, who reviewed this manuscript and proposed many improvements, and A. Solheim and A. Pittenger, who provided the physical measurements used in this study. We also thank J. Barron, A. Cooper, M. Hambrey, W. Hehrmann, and A. Porat for helpful suggestions and comments. K. Lieberkind is acknowledged for the useful suggestions she made through the review of the present manuscript. We also appreciate the help of the Lamont-Doherty Geological Observatory Borehole Research Group for useful advice and efficient training, particularly R. Anderson, P. Pezzard, D. Goldberg, R. Jarrard, C. Broglia, and X. Golovchenko. J. Clermontet and B. Biju-Duval made possible the collaboration between Nancy University and IFREMER to realize the present study. E. Le Drezen from IFREMER is acknowledged for her contribution to the data processing, as well as V. Tillot, who provided useful comments on the final manuscript. We also thank J. P. Maze for its contribution to the artwork included in this paper.

\section{REFERENCES}

Anderson, R. N., O'Malley, H., and Newmark, R. L., 1985. Use of geophysical logs for quantitative determination of fracturing, alteration, and lithostratigraphy in the upper oceanic crust, Deep Sea Drilling Project, Holes 504B and 556. In Anderson, R. N., Honnorez, J., Becker, K., et al., 1985. Init. Repts. DSDP, 83: Washington (U.S. Govt. Printing Office).

Augier, C., 1980. Diagraphies et matrices complexes. Bull. Cent. Rech. Explor.-Prod. Elf Aquitaine, 4:143-177.

Barron, J., Larsen, B., et al., 1989. Proc. ODP, Init. Repts., 119: College Station, TX (Ocean Drilling Program).

Bateman, R. M., 1985. Radiation logging. In Log Quality Control: Boston (International Human Resources Development Corporation Press), 154-156.

Borehole Research Group, 1988. Wireline Logging Manual: Palisades, NY (Lamont-Doherty Geological Observatory, Columbia Univ.).

Broglia, C., Schreiber, B. C., Cita, M. B., Chamley, H., and Dove, R., 1990. Mineralogical study of upper Miocene sediments from wireline logs and core measurements, Site 652, Ocean Drilling Program
Leg 107 (Tyrrhenian Sea). In Kastens, K. A., Mascle, J., et al., Proc. ODP, Sci. Results, 107: College Station, TX (Ocean Drilling Program), 229-243.

Burke, J. A., Campbell, R. L, and Schmidt, A. W., 1969. The lithoporosity crossplot. SPWLA, 10th Ann. Log. Symp. Trans., Paper J.

Chamley, H., 1989. Clay Sedimentology: Berlin (Springer-Verlag).

Doveton, J. H., 1986. Log Analysis of Subsurface Geology: Concepts and Computer Methods: New York (Wiley).

Easterbrook, D. J., 1964. Void ratios and bulk densities as means of identifying Pleistocene tills. Geol. Soc. Am. Bull., 75:745-750.

Edward, M. B., 1978. Glacial environments. In Reading H. G. (Ed.), Sedimentary Environments and Facies: Oxford (Blackwell Scientific), 416-438.

Ellis, D., Flaum, C., and Serra, O., 1988. Mineral logging parameters: nuclear and acoustic. Tech. Rev., 36:38-52.

Ellis, D. V., 1987. Well Logging for Earth Scientists: New-York (Elsevier).

Fisher, R. L., Jantsch, M. Z., and Comer, R. L., 1982. General Bathymetric Chart of the Oceans (GEBCO), Scale 1:10,000,000: Ottawa (Canadian Hydrographic Service), 5.9.

Goldberg, D., Wilkens, R. H., and Moos, D., 1987. Seismic modeling of diagenetic effects in Cenozoic marine sediments at Deep Sea Drilling Project Sites 612 and 613. In Poag, C. W., Watts, A. B., et al., Init. Repts. DSDP, 95: Washington (U.S. Govt. Printing Office), 589-599.

Hambrey, M. J., Larsen, B., Ehrmann, W. U., and ODP Leg 119 Shipboard Scientific Party, 1989. Forty million years of Antarctic glacial history yielded by Leg 119 of the Ocean Drilling Program. Polar Rec., 25:99-106.

Hayes, D. E., and Vogel, M., 1981. General Bathymetric Chart of the Oceans (GEBCO), Scale 1:10,000,000: Ottawa (Canadian Hydrographic Service), 5.13.

Herron, M. M., 1986. Mineralogy from geochemical well logging. Clays Clay Miner., 34:204-213.

Herzog, R. L., Colson, B., Seeman, M., O’Brien, H., Scott, D., McKeon, P., Wraight, J., Schweitzer, J., and Herron, M., 1987. Geochemical logging with spectrometry tools. Soc. Pet. Eng., Paper 16792.

Jarrard, R. D., Dadey, K. A., and Busch, W. H., 1989. Velocity and density of sediments of Eirik Ridge, Labrador Sea: control by porosity and mineralogy. In Srivastava, S. P., Arthur, M. A., Clement, B., et al., Proc. ODP, Sci. Results, 105: College Station, TX (Ocean Drilling Program), 811-835.

Mathis, B., 1988. Diagraphie et sédimentologie: Traduction du message diagraphique et reconnaissance des systèmes sédimentaires. Exemple des faciès hypersiliceux paléogènes et crétacès de l'offshore gabonais [Ph.D. dissert.]. Univ. de Nancy I, Nancy.

Mathis, B., Augier, C., Serra, O., Clermonte, J., and Lanau M., 1988. Les facies hypersiliceux de l'offshore Gabonais: analyse du message diagraphique en vue de la reconnaissance des syèstmes sédimentaires. Bull. Centres Rech. Explor. Prod. Elf-Aquitaine, 12:533-567.

Mathis, B., Bourquin, S., Clermontet, B., Didelot, B., and Alkhadour, G., 1989. Lithologic identification and sequential organization in the Paris Basin and in the Rhein Graben. SPWLA 12th Inter. Formation Evaluation Symp., Paris, Pap. DD.

Moore, C. H., 1989. Carbonate Diagenesis and Porosity: Amsterdam (Elsevier).

Pelline, C., 1989. Comparaison entre les calculs de porosité effectéus à partir de mesure in-situ dans les puits de forage (diagraphies) et les mesures obtenues sur carottes au cours de la campagne Ocean Drilling Program (ODP) 119 [Diplome d'Etudes Approfondies dissert.]. Univ. de Paris VI-Orsay, Paris.

Quirien, J. A., Gardner, J. S., and Watson, J. T., 1982. Combined natural gamma-ray spectral/lithodensity measurements applied to complex lithology. SPE of AIME, 57th Annual Fall Technical Conf. and Exhibit., New-Orleans, paper SPE 11143.

Quirien, J. A., Kimminau, S., La Vigne, J., Singer, J., and Wendel F., 1986. A coherent framework for developing and applying multiple formation evaluation models. Trans. SPWLA 27th Annu. Log. Symp., Paper DD.

Raymer, L. L., Hunt, E. R., and Gardner, J. S., 1980. An improved sonic transit time-to-porosity transform. Trans. SPWLA 21st Annu. Log. Symp., Paper P.

Schlumberger, 1972a. Log Interpretation Principles: New York (Schlumberger). 
Schlumberger, 1972b. The Essentials of Log Interpretation Practice: New York (Schlumberger).

Schlumberger, 1988. Log Interpretation Charts: New York (Schlumberger).

Serra, O., 1979. Diagraphies différées; bases de l'interprtation. Tome 1: Acquisition des données diagraphiques. Bull. Cent. Rech. Explor.Prod. Elf Aquitaine, Mem. 1.
Serra, O., 1985. Diagraphies diffres; bases de l'interprtation. Tome 2: Interprtation des données diagraphiques. Bull. Centres Rech. Explor.- Prod. Elf-Aquitaine, Mem. 7.

Date of initial receipt: 13 November 1989

Date of acceptance: 6 July 1990

Ms 119B-183 